Article

\title{
Consumers' Behavior in Selective Waste Collection: A Case Study Regarding the Determinants from Romania
}

\author{
Adina-Iuliana Jigani ${ }^{1}$, Camelia Delcea ${ }^{1, * \mathbb{D}}$ and Corina Ioanăș ${ }^{2}$ \\ 1 Department of Economic Informatics and Cybernetics, Bucharest University of Economic Studies, \\ 010552 Bucharest, Romania; adina.jigani@softscape.ro \\ 2 Department of Accounting and Audit, Bucharest University of Economic Studies, \\ 010374 Bucharest, Romania; corina.ioanas@softscape.ro \\ * Correspondence: camelia.delcea@csie.ase.ro
}

Received: 18 July 2020; Accepted: 10 August 2020; Published: 12 August 2020

\begin{abstract}
The increase in consumerism due to population growth, excessive advertising and the constant encouragement of buying behavior by advertising media and opinion formers comes with side effects for the environment and public health if it is not properly supported by a sustainable selective waste collection process. In this context, the paper aims at determining the impact of different elements on people's intention to participate in selective waste collection and on their behavior related to the collection process. Based on the literature, a series of variables were considered and a questionnaire was created in order to extract people's opinions related to the selective waste collection process. As discrepancies in findings might appear due to culture in various countries, the analysis has been conducted with reference to Romania's case. The waste collection situation in Romania is similar in some ways to other countries in the world, with some differences related to a small recycling rate compared to other countries in the European Union. In this context, it is important to identify the determinants of the consumers' behavior in selective waste collection and to act based on these findings. Creating better policies that can support the selective waste collection process will have results in increasing the waste collection rate, offering a clear and safer environment to all the citizens.
\end{abstract}

Keywords: selective waste collection; consumers' decisions; waste collection intention; structural equation modeling; Romania; waste collection determinants

\section{Introduction}

Selective waste collection is part of the municipal waste management processes and it involves the selective storage of recyclable waste (metal, glass, paper and plastic) from the wet biodegradable waste with the purpose of recycling it. Selective collection involves sorting the recyclable waste directly at the source, e.g., the waste sorting process is done directly by the person who generates it, while the transport of the two fractions (recyclable waste and biodegradable waste) is made by the sanitation operators.

Selective waste collection involves the separation of the two fractions by the waste producer, stating that the dry fraction (glass, paper, plastic, metal) must be stored properly. Therefore, it is mandatory for the collected waste to be dry and clean as the storage of wet waste or traces of food scraps can contaminate whole batches of waste and may make their recycling impossible. Small and large appliances, batteries, textiles, used cooking oils and light bulbs can also be selectively collected. The difference between these latter types and the main types of waste is the collection method as some of the latter can endanger people's lives, so they require a specific collection infrastructure. 
There are two ways in which the selective waste collection can be made: door-to-door collection or voluntary collection [1,2]. Door-to-door collection is done by each waste producer and involves the existence of separate bins for the two fractions for collection in a mixture or separately in individual containers using one of the color codes such as: orange for plastic, yellow for metal, blue for paper, green for glass, black for biodegradable waste and red for e-waste. By using the color scheme, the persons producing the waste can easily identify the specific bin for each type of waste, preventing the selection of the wrong bin, and can easily participate in the waste collection process without too much effort as, in most of the cases, the containers are located close to their home. For the voluntary collection method, the storage containers do not belong to certain manufacturers and they are located in places as accessible as possible for producers who voluntarily want to collect selectively. Also, as with door-to-door collection, there can be two containers for selective collection in the mixture, or there can be one for all types of waste.

In Romania, the municipal waste generated per capita has increased by $8.37 \%$ from $251 \mathrm{~kg} / \mathrm{capita}$ in 2012 to $272 \mathrm{~kg} / \mathrm{capita}$ in 2018 [3]. At the same time, the recycling waste rate reported for 2018 has been of only $11.1 \%$ of the generated waste, a value situated below the European Union average rate of $47 \%$ [3]. It is worth noting that the main method used for waste management in Romania is landfilling, followed by other forms of recovery and finally recycling. The landfilling of municipal waste is a method that should be carried out in maximum safety to prevent the entry in the soil of the chemicals resulting from the storage of waste. In the event of spills of hazardous chemicals into the soil, they can contaminate groundwater and soils in the region.

Additionally, to the best of our knowledge, there is little evidence regarding the waste collection process in the case of Romania and its main triggers. Hansmann et al. [4] underlined in their study that due to discrepancies in cultural and socio-economic factors, it might happen that the findings related to the determinant factors would be different. In this context, the current paper aims at analyzing the determinants of the consumers' decision to participate in the waste collection process. This issue is of major importance as an increase in the volume of waste generation is estimated in the following years [5]. According to a World Bank report, in 2030, in Europe and Central Asia there will be 440 million tons/year of waste produced, while in 2050 the volume will increase to 490 million tons/year, compared to 392 million tons/year reported for 2016 [5]. Strictly related to global mismanaged plastic waste generation, Lebreton and Andrady [6] show that without proper plastic waste management in 2060 , the amount of plastic generated worldwide would be close to 220 million tons/year, with $340 \%$ more than in the situation in which a proper waste management plan is used. Creating better policies that can support the selective waste collection process will have results in increasing the waste collection rate, offering a clear and safer environment to all citizens.

The remainder of the paper is structured as follows: Section 2 provides an overview of the waste situation in Romania and discusses it in comparison with other countries in the European Union. Section 3 presents a literature review on the topic of waste collection and management and underlines the main determinants presented by the scientific literature as having a high impact on the consumers' decisions related to waste collection and recycling. Section 4 discusses the methodology associated with this study, highlighting the elements considered in the questionnaire and stating the main hypotheses of the study. Section 5 analyzes the results gathered using the questionnaire and discusses the hypotheses validation. The paper ends with concluding remarks and a discussion related to the limitations of this study.

\section{The Waste Situation in Romania}

The situation of waste in Romania is similar in some respects to the situation of waste around the world. Simultaneously with population growth, the evolution of technology and the increase in the number of daily activities of people, the amount of waste they generate has also increased. The redefinition of social norms and the innovations that appear more and more often have led to a major transformation of society. It has been observed that people have started to buy goods that they 
end up not using or that are not a necessity, to buy more food than they can consume, to want to own the latest technologies on the market. This might be a consequence of the influence manifested by the aggressive advertising campaigns, which make people end up buying any product around which is in an excessive promotion process.

However, at the level of the European Union (EU), as well as at the level of Romania, there is a decrease in the quantity of municipal waste due to legislative changes and an increase in awareness of the impact of waste on the environment [7].

In the 2008-2018 period in the EU were generated on average $495 \mathrm{~kg}$ of waste per capita (Figure 1), of which $31.44 \%$ was deposited on the ground, $26.65 \%$ was recycled, $24.53 \%$ was incinerated, $14.67 \%$ was composted and $2.71 \%$ was treated by other methods [8]. As can be seen in Figure 2 and from the data offered by Eurostat [8], in the analyzed period 2008-2018, most of the generated waste was deposited on the ground, an average of $155.6 \mathrm{~kg}$.

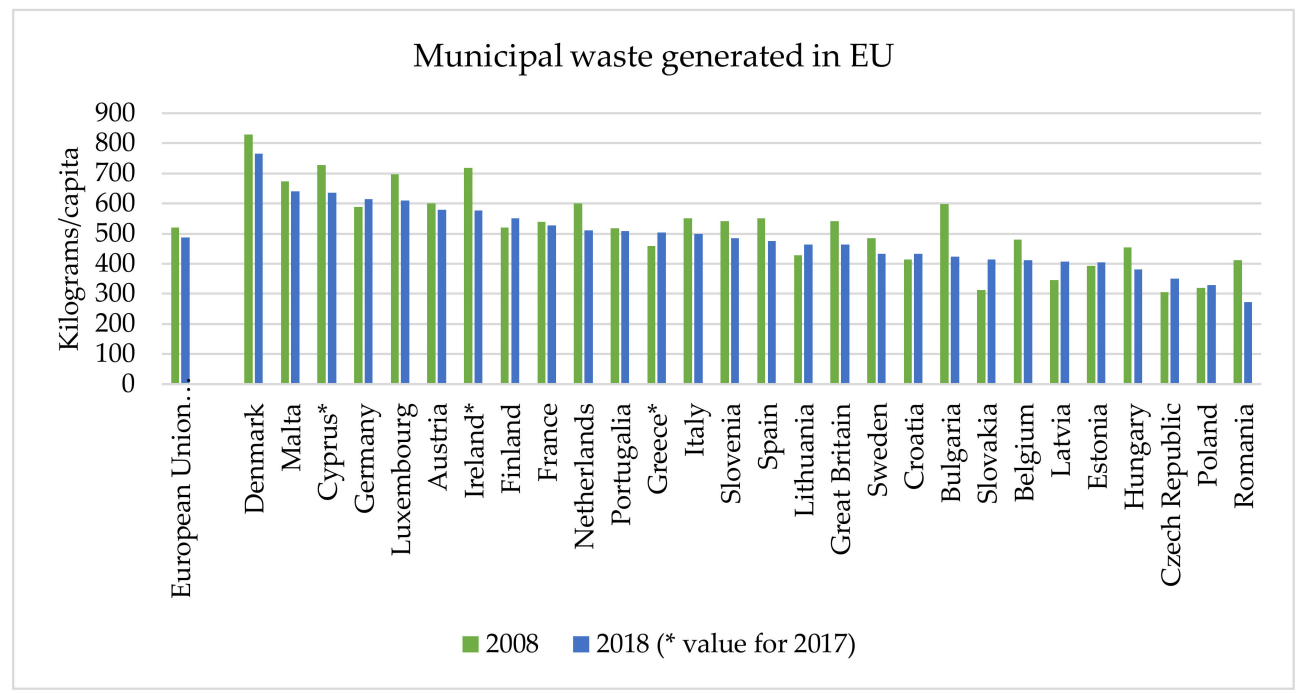

Figure 1. Municipal waste generated in the EU.

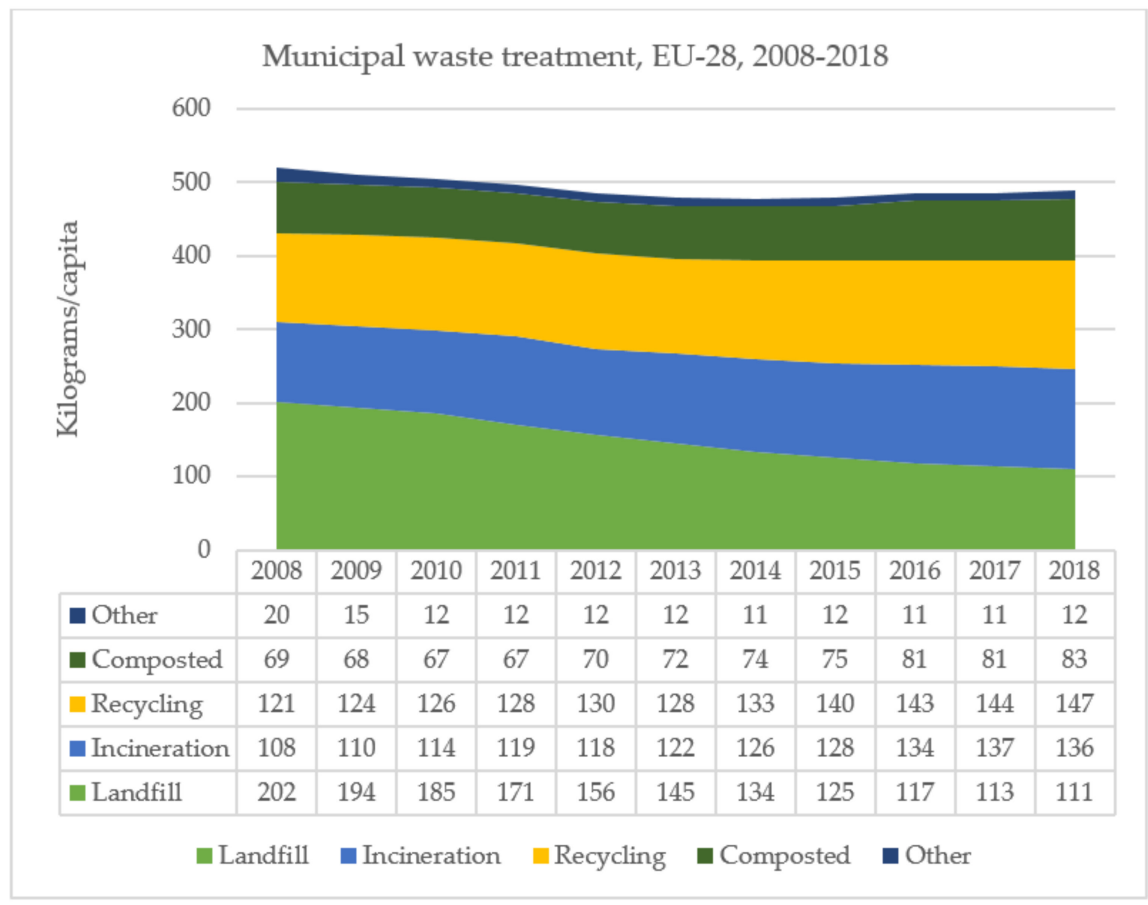

Figure 2. Municipal waste treatment in the EU. 
The country that generated the most waste in 2018 was Germany, followed by France, Great Britain and Italy [8]. Romania ranks 11th place out of 28 and generated 5,296,000 tons of waste and $272 \mathrm{~kg} / \mathrm{capita}$ [8]. The countries that have generated the least amount of waste are Malta and Luxembourg, with less than 400,000 tons, which might be connected to the small area and the smaller number of inhabitants compared to other EU countries.

In Romania, there is a significant decrease in the amount of waste generated. It can be observed that from 2008 to 2018 municipal waste generated decreased by approximately $139 \mathrm{~kg} / \mathrm{capita}$, due to national and European regulations to reduce waste, the reduction of the amount of packaging used in various economic activities and the placing on the market of more environmentally friendly alternatives or ones which can be reused several times for the purpose for which they were produced before they lose their usefulness. Figure 3 shows a downward trend until 2012, then a slight increase in 2013, followed by a decrease in 2014 and 2015 - the year in which the lowest value was recorded in the analyzed period. In 2017 and 2018, the amount was stabilized around $272 \mathrm{~kg} / \mathrm{capita}$ (approximatively 5 million tons of waste) [8].

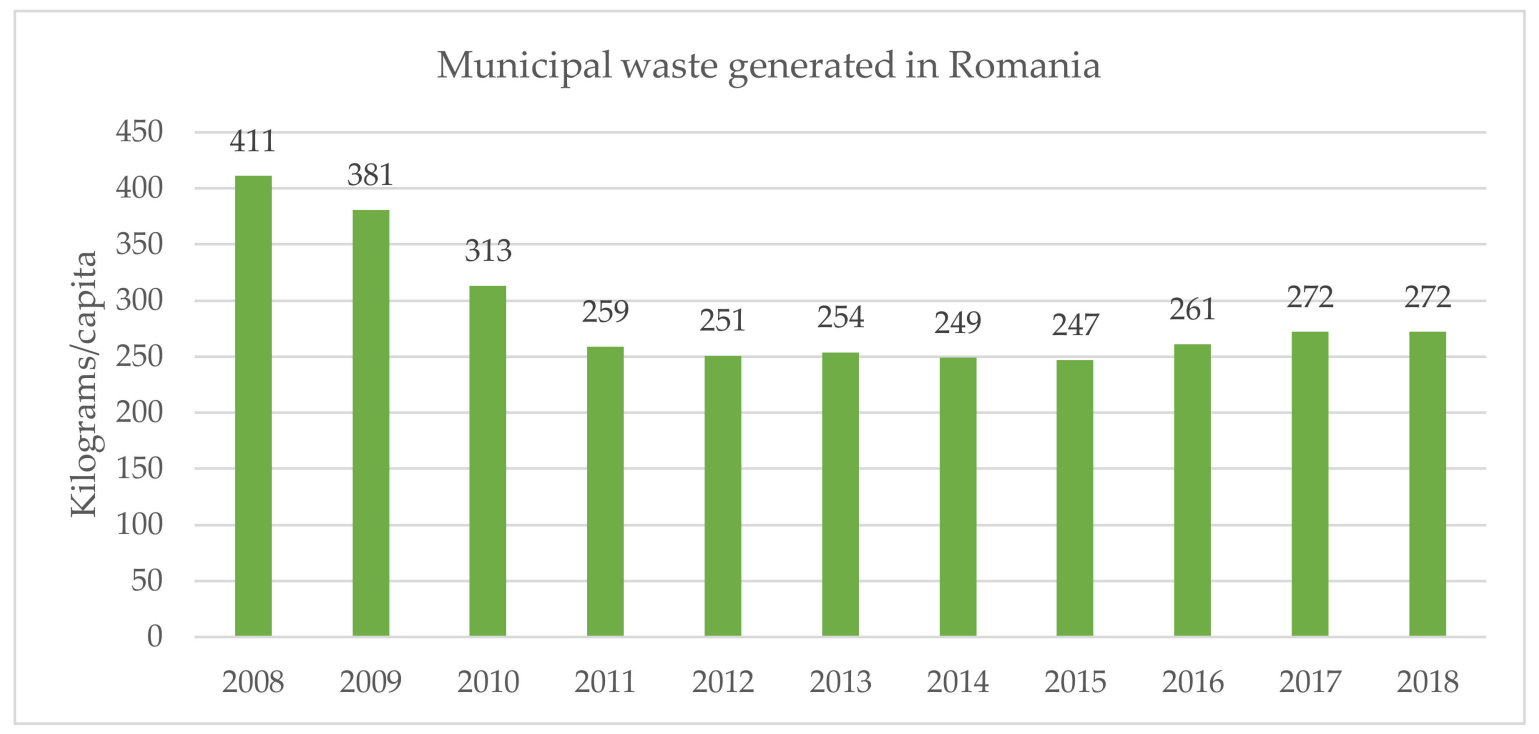

Figure 3. Evolution of municipal waste generated in Romania.

Figure 4 presents the municipal waste recycling rates in 2017 for the $28 \mathrm{EU}$ countries. This indicator measures the percentage of recycled waste in the total amount generated in each country and includes material recycling, composting and anaerobic digestion. As can be observed in Figure 4, Germany is the country with the highest recycling rate (67.2\%) in the EU. Based on this result, it can be stated that even if it is the country that generates the largest amount of waste, the country also manages properly a large amount of the generated waste. On the other hand, Romania is among the last two countries with respect to this indicator, scoring only $14 \%$ for the municipal waste recycling rate, while the EU average for municipal waste recycling is $46.2 \%$.

In 2018, the rate of the municipal waste recycling in Romania decreased by $3 \%$, reaching $11 \%$, which makes it almost impossible to reach the 50\% target imposed by the European Union for each member country by the end of 2020 .

Among the objectives that Romania must achieve by the end of 2020 there are also recycling or reuse of over $70 \%$ of the amount of construction waste, recovery of $60 \%$ of packaging waste from the total placed on the market, annual collection of $4 \mathrm{~kg} /$ inhabitant of electrical waste, selective collection of biowaste for composting and reducing the amount of biodegradable waste deposited on the ground by $35 \%$ compared to the amount deposited since 1995 [9]. Failure to comply with EU rules has a major impact not only on the environment, but also on the economy because the failure of these targets will generate very high penalties to be paid to the European Union. 


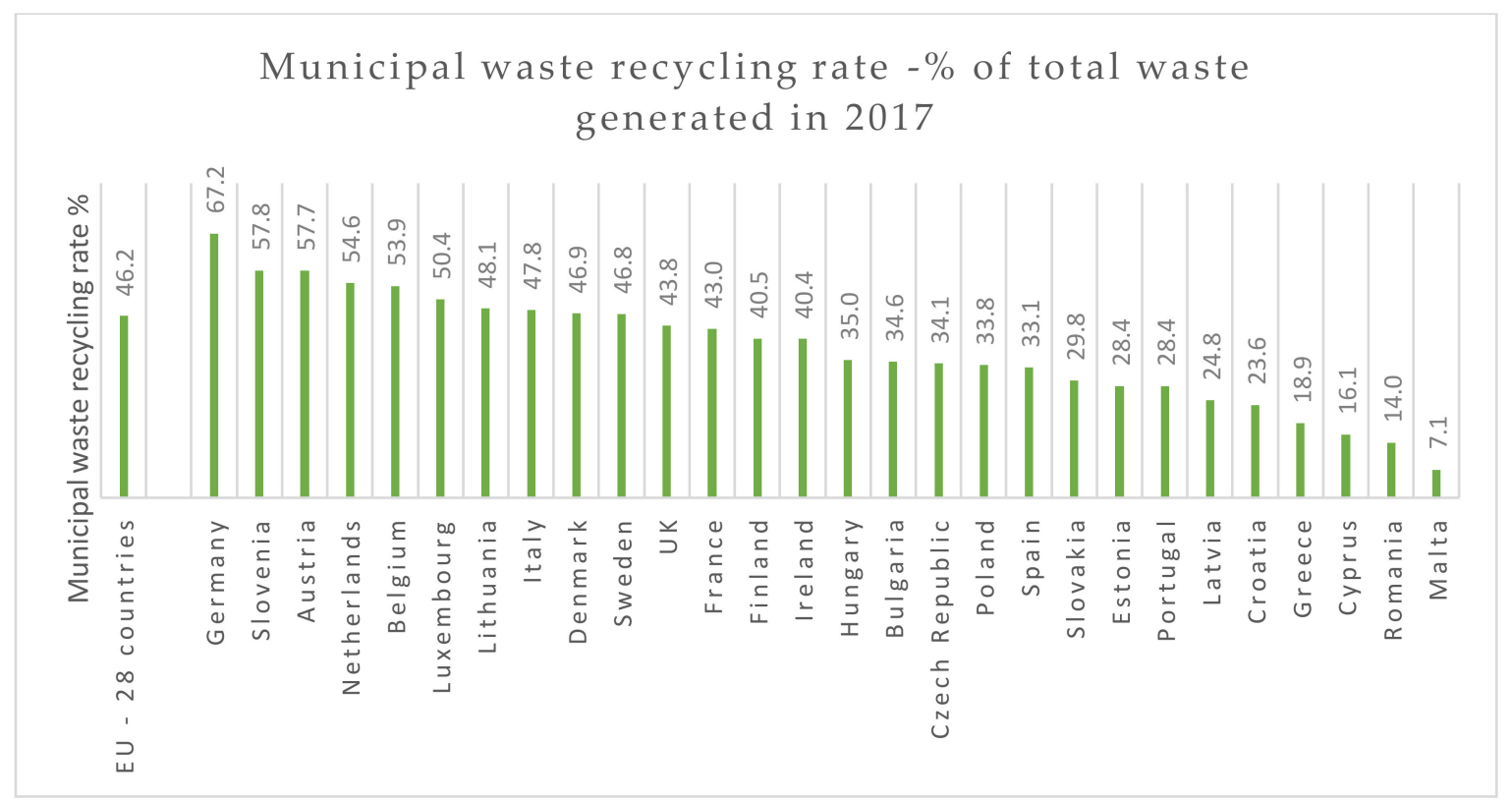

Figure 4. Municipal waste recycling rate in EU.

Even though from 1 January 2019, the system "pay for how much you throw" has become mandatory, it is not implemented throughout the country. As a result, the amounts of waste that end up being deposited on the ground are fluctuating around $70 \%$ of total municipal waste-Figure 5 . Although the price of waste landfill per ton increased by $266 \%$ in 2020 compared to 2019 [7] the territorial administration has not succeed to make available to all citizens a performant infrastructure for selective collection, even if the legislation imposes an obligation to take these measures.

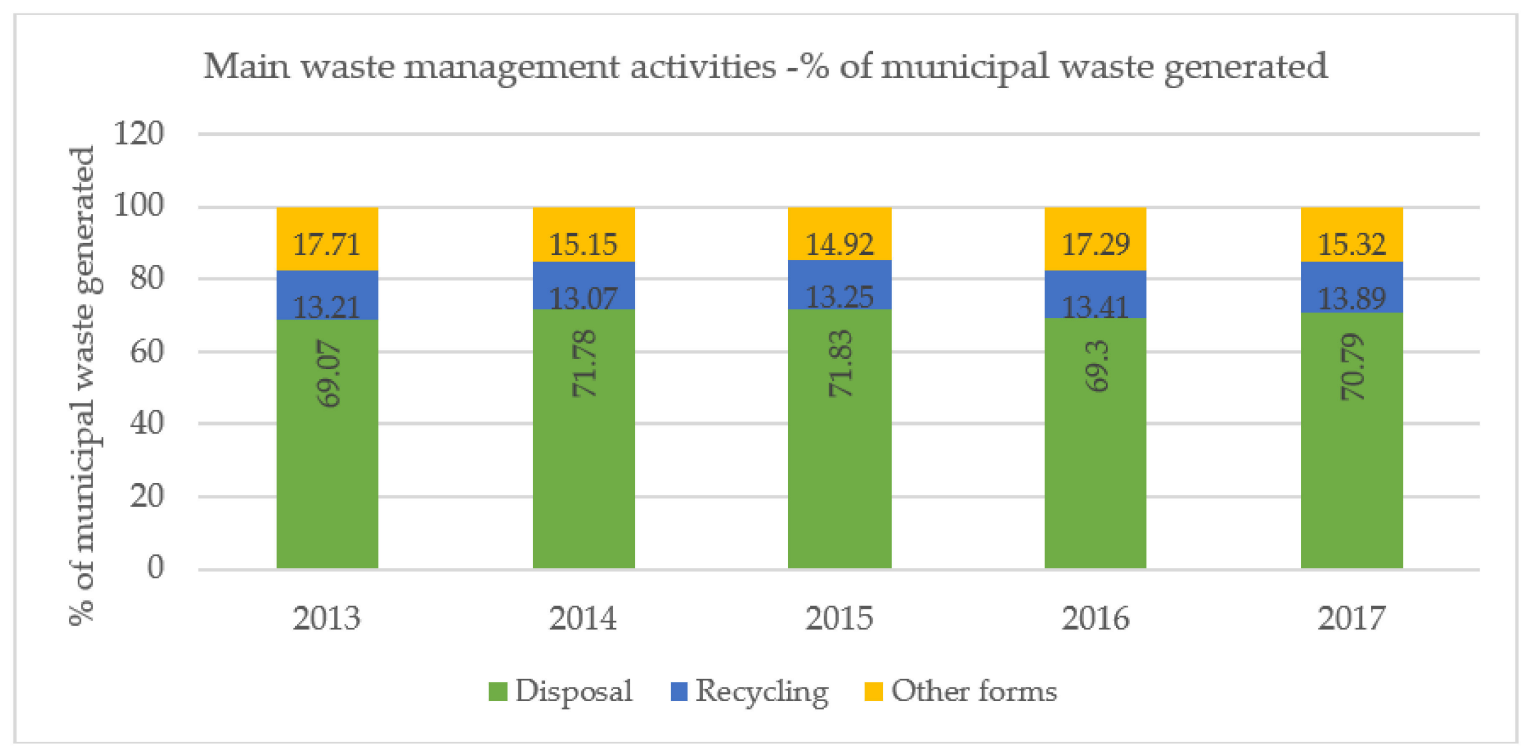

Figure 5. Main waste management activities.

At this moment there are no concrete data to identify the rate of selective collection in Romania, but we can assimilate this rate to the recycling rate because the amount of waste recycled represents the amount of waste collected selectively and met all the specifications of selective collection.

The situation in Romania is different from this point of view from other EU countries, as the recycling rate is much lower compared to the other states. The decrease recorded for 2018 can only make the target difficult to achieve. 
As can be seen in Figure 5, the main method of waste management in Romania is landfilling, followed by other forms of recovery and recycling. Landfilling of waste must be carried out in maximum safety so as to prevent entry into the soil of chemicals resulting from the storage of waste. In the event of spills of hazardous chemicals into the soil, they can contaminate groundwater and soils in the region. Landfills also release harmful gases into the atmosphere that contribute to questionable air quality for those living near them, especially in the hot season [10].

However, in Romania there are also examples of good practice that have complied with European regulations and have exceeded the target of $50 \%$. Such an example is represented by the city of Târgu Lăpuș in Maramureș County.

Târgu Lăpuș was the first city in Romania to be accepted in the "Zero Waste" network [11] in 2014, which was later joined by nine other Romanian municipalities (Calnic, Cociuba Mare, Codlea, Iași, Mizil, Recaș, Sălacea, San Crai and Vetrișoaia).

In 2013, the rate of selective collection in Târgu Lăpus was 58.54\%, and the amount of waste generated was $212 \mathrm{~kg} /$ inhabitant, $37 \mathrm{~kg}$ less than the national average [12]. For 2020 the aim is to reduce the amount of household waste deposited by $90 \%$ compared to the amount for 2010 . Regarding the collection of waste, it should be mentioned that in this city, selective collection is practiced directly at the source.

The situation of waste in Romania is an important and actual phenomenon for which solutions are sought throughout society in order to reduce and reuse the generated waste. As a result, we aim at identifying the factors that determine the consumers' selective collection behavior.

\section{Literature Review}

As the scientific literature related to this field is vast, we have extracted for the literature review a limited number of papers, trying to cover various approaches from different parts of the world. The literature review is discussed from three points of view: the variables considered in the research papers, the methods used in research and the tested hypotheses.

\subsection{Research Variables}

Considering the literature, it has been observed that various indexes have been used when discussing the determinants of the selective waste collection and engagement in the recycling process. As a result, 22 determinants have been identified, as shown in Table 1. Some of them have been listed directly in the mentioned papers (under the same or similar names), while for the other we have identified in the questionnaire used by the authors a series of questions which were referring to the presented determinants.

Based on the data in Table 1, it has been observed that the most used variables in the papers addressing the consumers' behavior related to selective waste collection and recycling have been the Social Norms, Attitude, Perceived Behavioral Control and Selective Collection Intention.

Table 1 shows a slight increase in the number of indices analyzed from year to year. With the development of technology and the advancement of research methods, researchers have begun to consider that the number of behavioral factors has increased. As a result, in order to conduct a valid study, one must consider as many influencing factors as possible. Among the factors that have recently begun to be considered in the research literature, one can name the social networks included in the Social Media indicator in the analysis, non-governmental organizations (NGOs), Global Warming, Government Measures and the possibility of storage conditioned by the availability of a space to allow the temporary storage of waste before it reaches the specially designed bins (Storage Space Existence)—Table 1.

Table 1 also shows the countries for which the research was conducted, thus a high interest in Asia can easily be observed regarding the situation of waste in this continent, as more than half of the studies discuss countries from this part of the world. 
Table 1. Selected references and the determinants used in research.

\begin{tabular}{|c|c|c|c|c|c|c|c|c|c|c|c|c|c|c|c|c|c|c|c|c|c|c|c|c|}
\hline \multirow{2}{*}{ Author } & \multicolumn{22}{|c|}{ Determinants/Questions Referring to These Determinants Used in Research Papers * } & \multirow{2}{*}{ Year } & \multirow{2}{*}{ Country } \\
\hline & 1 & 2 & 3 & 4 & 5 & 6 & 7 & 8 & 9 & 10 & 11 & 12 & 13 & 14 & 15 & 16 & 17 & 18 & 19 & 20 & 21 & 22 & & \\
\hline Boldero [13] & $\mathrm{x}$ & $\mathrm{x}$ & $\mathrm{x}$ & $x$ & $\mathrm{x}$ & $\mathrm{x}$ & & & & & & $\mathrm{x}$ & $\mathrm{x}$ & & & & & & & & & & 1995 & Australia \\
\hline Garces et al. [14] & $\mathrm{x}$ & & & & & & $x$ & & & & & $x$ & & & & & & & & & & & 2002 & Spain \\
\hline Tonglet et al. [15]** & $\mathrm{x}$ & $\mathrm{x}$ & $\mathrm{x}$ & $\mathrm{x}$ & & & & & & & & & $\mathrm{x}$ & & & & $\mathrm{x}$ & & & & & & 2003 & United Kingdom \\
\hline Valle et al. [16] & $\mathrm{x}$ & $\mathrm{x}$ & $x$ & & $\mathrm{x}$ & $\mathrm{x}$ & & & & $\mathrm{x}$ & & $x$ & & & & & $x$ & & & & & & 2005 & Portugal \\
\hline Mahmud and Osman [17] & $\mathrm{x}$ & $\mathrm{x}$ & $\mathrm{x}$ & $x$ & & & & & & & & & & & & & & & & & & & 2010 & Malaysia \\
\hline Lee and Paik $[18] * *$ & & $\mathrm{x}$ & & & & $\mathrm{x}$ & & & & & & & & & & & & & & & & & 2010 & Korea \\
\hline Klöckner and Oppedal [19] & $\mathrm{x}$ & $\mathrm{x}$ & $\mathrm{x}$ & $x$ & & & $x$ & & & & & & $\mathrm{x}$ & & & & $\mathrm{x}$ & & & & & & 2010 & Norway \\
\hline Latif et al. [20] ** & $\mathrm{x}$ & & & $x$ & & & & & & & & & & & & & & & & & & & 2011 & Malaysia \\
\hline Bezzina and Dimech [21] ** & $\mathrm{x}$ & & & $\mathrm{x}$ & $\mathrm{x}$ & & $x$ & & & & & & $\mathrm{x}$ & & $\mathrm{x}$ & & & & & & & & 2011 & Malta \\
\hline Wan et al. [22] ** & $\mathrm{x}$ & $\mathrm{x}$ & $\mathrm{x}$ & $\mathrm{x}$ & & & $x$ & & & & & & & & & & $\mathrm{x}$ & $\mathrm{x}$ & & & & & 2014 & China \\
\hline Amini et al. [23] & $\mathrm{x}$ & $\mathrm{x}$ & $\mathrm{x}$ & & & $\mathrm{x}$ & & & & & & & & $x$ & & & & & & & & & 2014 & Malaysia \\
\hline Byrne and $O^{\prime} \operatorname{Regan}[24] * *$ & & $\mathrm{x}$ & & & $\mathrm{x}$ & & & & & $x$ & & & & & & & & & & & & & 2014 & Ireland \\
\hline Nguyen et al. [25] ** & $\mathrm{x}$ & $\mathrm{x}$ & & & $\mathrm{x}$ & & $x$ & & $\mathrm{x}$ & & & & & & & $\mathrm{x}$ & $\mathrm{x}$ & & $\mathrm{x}$ & & & & 2015 & Vietnam \\
\hline Yahya et al. [26] & & & & & & $\mathrm{x}$ & $x$ & $\mathrm{x}$ & & & & & & & & & & & & & & & 2016 & Malaysia \\
\hline Hynes and Wilson [27] & $\mathrm{x}$ & & & & $x$ & & & & & & & & $x$ & & & & & & & & & & 2016 & n.a. (Facebook) \\
\hline Miliute-Plepiene et al. [28] & $\mathrm{x}$ & & & & & & & $x$ & & & $\mathrm{x}$ & & & & & $\mathrm{x}$ & & & & & & & 2016 & Lithuania and Sweden \\
\hline Yuan et al. [29] & $\mathrm{x}$ & $\mathrm{x}$ & $\mathrm{x}$ & & & & & & $\mathrm{x}$ & & & & & & & & & & & & & & 2016 & China \\
\hline Zhang et al. [30]** & $\mathrm{x}$ & $\mathrm{x}$ & $\mathrm{x}$ & $x$ & & & & & & & & & & & & & & & & & & & 2016 & China \\
\hline Nduneseokwu et al. [31] & $\mathrm{x}$ & $\mathrm{x}$ & & $x$ & $x$ & & & & & $x$ & & & & & $x$ & & & & & & & & 2017 & Nigeria \\
\hline Nguyen et al. [32] & $\mathrm{x}$ & $\mathrm{x}$ & & & & & & & & & & $\mathrm{x}$ & & & & & & & & $x$ & & & 2017 & Vietnam \\
\hline Pop et al. [33] ** & & $\mathrm{x}$ & & & & $x$ & $x$ & $x$ & $x$ & $x$ & $\mathrm{x}$ & & & & & & & & & & & & 2015 & Romania \\
\hline Meng et al. [34] ** & $\mathrm{x}$ & $\mathrm{x}$ & & & $x$ & $\mathrm{x}$ & & $\mathrm{x}$ & & $x$ & $\mathrm{x}$ & & & & $x$ & & & & $\mathrm{x}$ & & & & 2018 & China \\
\hline Rosenthal [35] ** & & & $\mathrm{x}$ & $x$ & $x$ & & & & & & & & $x$ & & & & & & & & & & 2018 & Singapore \\
\hline Strydom [36] & $\mathrm{x}$ & $\mathrm{x}$ & $\mathrm{x}$ & $x$ & & & & & & & & & & & & & & & & & & & 2018 & South Africa \\
\hline
\end{tabular}


Table 1. Cont

\begin{tabular}{|c|c|c|c|c|c|c|c|c|c|c|c|c|c|c|c|c|c|c|c|c|c|c|c|c|}
\hline \multirow{2}{*}{ Author } & \multicolumn{22}{|c|}{ Determinants/Questions Referring to These Determinants Used in Research Papers * } & \multirow{2}{*}{ Year } & \multirow{2}{*}{ Country } \\
\hline & 1 & 2 & 3 & 4 & 5 & 6 & 7 & 8 & 9 & 10 & 11 & 12 & 13 & 14 & 15 & 16 & 17 & 18 & 19 & 20 & 21 & 22 & & \\
\hline Sujata et al. [37] ** & $\mathrm{x}$ & $x$ & & $x$ & $x$ & & & $x$ & & & & & & & $x$ & & & $x$ & & & & $x$ & 2019 & Malaysia \\
\hline $\mathrm{Ng}[38] * *$ & & $\mathrm{x}$ & & & $\mathrm{x}$ & & & & & & & $x$ & $x$ & & & & & & & & & & 2019 & China \\
\hline Nguyen et al. [39] & $x$ & $\mathrm{x}$ & & $\mathrm{x}$ & & & & $x$ & & & & $x$ & $\mathrm{x}$ & & & & & & & & & & 2019 & Vietnam \\
\hline Wang et al. [40] & $x$ & $x$ & $x$ & $x$ & & & & & & & & & & & $\mathrm{x}$ & & & & & & & & 2019 & China \\
\hline $\begin{array}{c}\text { Pamuk and } \\
\text { Kahriman-Pamuk [41] }\end{array}$ & $\mathrm{x}$ & $\mathrm{x}$ & $\mathrm{x}$ & $\mathrm{x}$ & & & & & & & & & & & & & & & & & & & 2019 & Turcia \\
\hline Delcea et al. [42] & $x$ & $x$ & & $x$ & & & $x$ & $x$ & $x$ & & $\mathrm{x}$ & $\mathrm{x}$ & & $\mathrm{x}$ & & & & & & & $x$ & $x$ & 2020 & Romania \\
\hline
\end{tabular}

*1-Social Norms, 2-Attitude, 3-Perceived Behavioral Control, 4-Intention, 5-Environmental Knowledge, 6-Responsible Consumer Behavior, 7-Awareness, 8-Government Measures, 9-Responsibility, 10-Collection Infrastructure, 11-Social Influence, 12-Convenience, 13-Previous Recycling Experience, 14-Social Media, 15-Reward, 16-Trust, 17-Personal Rules, 18-Penalty/Taxation, 19-Storage Space Existence, 20-Global Warming, 21—Government, 22-Non-governmental Organizations (NGOs). ** for these authors we have extracted the determinants based on the questions referring to these determinants. 
As for the variables' influence, there are situations in which most of the studies indicate a positive or a negative influence over the consumers' behavior, but there are also studies which prove the opposite. In order to have an adequate picture, we will discuss in the following the ideas within each variable and how it has scored in different studies related to selective waste collection and recycling.

\subsubsection{Social Norms}

Social norms derive from the way a person perceives that the people who matter to them or society in general would expect them to act. Social norms represent the types of behavior that society accepts or that other people expect the individual to adopt [27].

As previously mentioned, Social Norms is the variable found in most research. According to the study conducted by Amini et al. [23], which aimed to investigate the influence of economic instruments (taxation and reward) on household recycling intentions in order to help the Malaysian government to enforce the necessary recycling regulations, by applying several multiple regression analyzes, it was shown that the factor Social Norms has a significant impact on the intention to recycle, even though the impact was smaller than that of attitude. Mahmud and Osman [17] considered social norms in their study and found that there is a significant influence on recycling behavior. Valle [16] showed that social norms have a significant impact on both personal norms and on recycling behavior. For the case of young people, Halder and Singh [43] observed that social norms have the strongest and most significant impact on students' intention to recycle. To same conclusions were highlighted by Nduneseokwu et al. [31] in a study on the population of Nigeria. A positive relation was found even by Miliute-Plepiene et al. [28] in the case of Lithuanian persons, while for the Norway consumers, the results were not statistically significant. On the other hand, Boldero [13] determined that the norms did not have a significant impact on behavior or on selective collection intent.

\subsubsection{Social Media}

Due to the development of social media, the social influence manifested on these platforms has been analyzed in order to see whether it has an impact on the consumers' behavior in relation to the recycling and selective waste collection process [44-46].

Sujata et al. [37] analyzed the role of social media in consumers' recycling habits and established that social media usage has a positive, significant, but weak predictor of behavioral intention. The same results were obtained by Delcea et al. [42].

\subsubsection{Attitude}

Attitude towards behavior represents the positive or negative feelings of the individual when adopting a certain behavior [45]. It is determined by an assessment of one's beliefs and of the consequences that result from a behavior, and it depends on the desirability of these consequences [26].

Halder and Singh [43] showed that attitude is the second strongest variable that positively influences the intention of young people to recycle. The positive and significant influence of the attitude on the intention to participate in the selective collection of e-waste has been underlined in the study conducted by Nduneseokwu et al. [31]. The authors showed that attitude is the third most significant factor influencing intention after social norms and environmental knowledge. A positive significant impact on the intention to recycle is found in Delcea et al. [42]. Even in this case, there are studies that found that attitude does not have a significant impact on the intention of selective collection at source, such as the study conducted by Nguyen [25] on the inhabitants of Hanoi, Vietnam. Even more, Ng [38] proves a significant negative relationship between attitude and the recycling behavior.

\subsubsection{Perceived Behavioral Control}

Perceived behavioral control (PBC) represents the beliefs of individuals regarding the difficulty and control of a specific behavior [47]. More specifically, PBC reflects two dimensions: the external 
conditions of a person that can increase or moderate the ability to adopt a certain behavior and the perceived ability to perform the behavior [16].

Perceived behavioral control was shown to have a positive and significant influence on consumer behavior in the study conducted by Strydom [36], having no significant influence on the selective collection intention. Similar results regarding the influence on consumers' behavior were found by Ajzen [48]. As for the influence on selective collection intention, a general opinion has not been reached yet: Chu and Chiu [49] found a positive relationship, while Boldero [13] and Halder and Singh [43] found no significant impact.

\subsubsection{Intention}

Intention measures the desire of a person to adopt a certain behavior and it is supposed to be a determinant of behavior [50]. Boldero [13] found a positive and significant impact of intention on selective collection behavior. Similar results were found in $[36,42]$.

\subsubsection{Convenience}

The term convenience refers to the ease of use related to the sorting infrastructure and the proper understanding of how to use it [51]. According to Boldero [13], convenience has a negative and significant impact on the selective collection intention. $\mathrm{Ng}$ [38] found a negative and significant influence on consumers' behavior, while Delcea et al. [42] found a reduced positive influence on the behavior of e-waste recycling. Some of the differences in the approaches might be because in some studies the questions included in the questionnaires referred to the inconvenience rather than to the convenience of engaging in certain activities.

\subsubsection{Government Measures}

The role of the Government in protecting the environment is very important. Government measures are represented by laws and regulations in the field of environmental protection to encourage the reduction of consumption [26]. Even for this determinant, the opinions do not emerge, with some of the authors finding a positive influence on the behavior [42], while others state that the impact is not significant [28].

\subsubsection{Awareness}

Awareness refers to understanding the effects of waste on the environment and the emergence of a persistent public concern [26]. According to Meng et al. [34], awareness has the highest impact on the selective collection behavior among all the considered variables. A positive and significant impact has also been found in a study related to the determinants of recycling decision regarding the e-waste products [42]. Awareness is one of the factors regarding which different points of view have been encountered in the literature. Considering the Theory of Planned Behavior (TPB) discussed in the papers related to recycling, it can be observed that a series of approaches emphasize the role of awareness on the consumers' intention, further connected to the consumers' decision to recycle. For example, Davis and Morgan [52] state in a paper dealing with waste behavior in Bristol City that the increase of waste minimization awareness should contribute to future recycling levels and to reducing the total waste generated. Wan et al. [22] considered the awareness of consequences as an underlining factor for behavioral intention, but found that even though the connection was positive and significant, the influence was low. Furthermore, Kite et al. [53] underlined the fact that some variables, such as awareness, are casually linked to distant outcomes such as behavior through the connection of other variables such as attitudes, social norms, intentions. Meng et al. [34] included environmental awareness as part of the environmental attitudes with a direct influence on the residents' disposal behavior. Klockner and Oppendal [19] considered awareness as an influence factor for personal norms, which further had an influence on recycling habit and intention, both of which influenced the recycling behavior. Bezzina and Dimech [21] propose a model in which behavior is 
influenced by personal norms, whose effect is mediated by two factors: the awareness of consequences and ascription to responsibilities. On the other hand, a series of studies which have started from the Schwartz model of altruistic behavior [54] have considered the direct influence of awareness on behavior. Garces et al. [14] used in their model eight direct variables influencing the recycling behavior, one of them being awareness. Yahya et al. [26] tested in their paper a hypothesis sustaining that "there is a significant and positive relationship between public awareness and environmentally friendly consumer behavior" (p.3), concluding that "awareness appeared to have the highest positive significant relationship with environmentally friendly consumer behavior". Nevertheless, considering Grob's model of environmental behavior [55], environmental awareness was listed among the four direct determinants of general environmental behavior [16].

\subsubsection{Responsibility}

In this context, responsibility is the obligation of people to perform the self-assigned objective to protect the environment and properly manage the waste they generate [18]. Responsibility positively influences the intention to recycle electronics among Romanians, but does not have a significant contribution [42].

\subsubsection{Personal Norms}

Personal norms reflect individuals' beliefs about how they should behave [16]. When individuals act in accordance with these rules, they experience a strong sense of pride. Usually, if a personal norm is violated, they feel guilty [16].

According to Nguyen et al. [25], personal norms make a significant and direct contribution to predicting the intention of selective collection directly from the source.

\subsubsection{Trust}

Trust is a set of behaviors that reflect the expectations of individuals they have from different entities-in this case from the authorities-and regards the means through which the entities succeed in managing the waste situation [28]. In the study conducted by Nguyen et al. [25], trust is the variable that makes the greatest contribution to predicting the intent of selective collection of the Hanoi community.

\subsubsection{Environmental Knowledge}

Environmental knowledge refers to the knowledge, information and skills necessary for individuals to properly sort waste, to understand its impact on the environment, along with their knowledge of selective collection programs, collection stations and infrastructure provided by the authorities [34]. According to Meng et al. [34], environmental knowledge has a significant impact on consumer behavior in China.

\subsubsection{Collection Infrastructure}

Selective collection infrastructure refers to the access of individuals to collection stations, their condition, their physical storage capacity and the number of the available collection stations [34]. It has been determined that selective collection infrastructure has a significant role in determining consumer behavior [34].

\subsection{Research Methods and Tested Hypotheses}

Various approaches have been used for highlighting the connection between the considered determinants and the consumers' behavior. With all these, two methods have been extensively employed in the research literature associated to this field: regression analysis [15,18,21,32,41] and factor analysis $[14,17,22,26,29,34,39,42,43]$. 
As for the tested hypotheses, Rosenthal [35] tested seven hypotheses which state that intention is positively related to procedural information seeking; procedural information seeking positively influences the recycling behavior; procedural information seeking mediates the relationship between recycling intention and recycling behavior; procedural information seeking has a positive impact on recycling-related behavioral control; behavioral control mediates the relationship between information seeking and recycling behavior; higher procedural information seeking increases the positive relation between recycling intention and recycling behavior and behavioral control mediates the moderation effect [35]. Among the considered hypotheses, all but one (related to the mediation role of procedural information seeking on the positive relation between recycling intention and recycling behavior) have been accepted.

Nguyen et al. [32] tested five hypotheses. Based on the analysis, the authors rejected only one hypothesis related to the positive relationship between personal norms and recycling behavior. Based on the results, a positive relationship was observed between attitude, social norms, global warming and recycling behavior, while recycling behavior scored a negative relationship with recycling inconvenience.

Yuan et al. [29] considered ten hypotheses. Nine of the hypotheses have been validated; the one not validated referred to the fact that an individual who has a positive attitude regarding the selective collection of food waste is more likely to adopt this behavior [29]. Among the validated hypotheses we mention the existence of a positive relationship between: perceived behavioral control and behavior, subjective norms and behavior, attitude and behavior, personal norms and behavior, social norms and attitude and negative relationships between attitude and denial of responsibility, denial of responsibility and behavior [29].

The study conducted by Tonglet et al. [15] presents a model in which attitude, social norms and control of perceived behavior influence the intention of selective collection, and intention influences behavior. The results of the study showed that a positive attitude towards selective collection was the best predictor of behavior, and it was also the strongest factor correlated with the intention of selective collection [15].

Wang et al. [40] carried out a study focused on the willingness of consumers to engage in on-line recycling behavior. The authors tested the following hypotheses: attitude positively and significantly influences residents' desire to participate in selective on-line e-waste collection; subjective rules positively and significantly affect residents' desire to participate in online recycling of e-waste; perceived behavioral control positively and significantly influences residents' desire to participate in online recycling of e-waste [40]. Additionally, a positive relationship was tested between economic motivation, income level and level of education on the willingness to participate in an e-waste on-line recycling process. The last hypotheses tested were the moderation of the willingness by the level of education or the level of the resident's income. Across the eight hypotheses, all have been supported, except for the hypothesis referring to the moderate role of the education level between the subjective norms and the willingness of the residents to participate in e-waste on-line recycling.

Valle et al. [16] considered fourteen hypotheses. Twelve of them have been supported: social norms and control of perceived behavior positively influence behavior, knowledge of the environment and the convenience of using the collection service logistically positively influence perceived behavioral control, social norms positively influence personal norms, the effect of social norms on behavior is mediated by personal norms, the positive influence of personal norms on behavior is stronger for those who have a positive attitude about selective collection. A positive attitude towards ecology has a positive influence both for the general opinion about recycling and for the perceived behavioral control. Hypotheses regarding the positive influence of individuals' personal values on perceived behavioral control and general opinion about recycling were also tested. Another hypothesis tested and validated was that of the positive influence of the communication strategy on environmental knowledge. The hypotheses that were not statistically validated stated the positive influence of the communication strategy on the perceived behavioral control and the attitude on the behavior [16]. 


\section{Material and Methods}

\subsection{Survey Design}

Based on literature review presented in Section 2 of this paper, a 53-question survey was created. The questions were designed starting from the questions used by the other authors who addressed selective collecting or recycling issues in their works. Some of these works are listed in the following: [14-16,21,22,24-38,40-42]. The questions can be divided into three main groups: 10 demographic and socio-economic questions, 1 control question in which the respondents were asked to name the items they have selectively collected in the past months and 42 questions designed for determining the impact of 11 determinants on the selective collection intention and behavior.

Considering the literature, the following determinants have been broadly observed: Attitude, Perceived Behavioral Control, Intention, Environmental Knowledge, Awareness, Government Measures, Responsibility and Waste Collection Infrastructure, and were included in the questionnaire, along with some other elements less studied in the literature.

As a result, the following elements were considered: Attitude (AT), Awareness (AW), Perceived Behavioral Control (PBC), Convenience (CON), Environmental Knowledge (EK), Selective Collection Behavior (SCB), Government Measures (GM), Intention (INT), Waste Collection Infrastructure (INFR), Social Norms (SN), Responsibility (RSP), Reward (RW) and Taxation (TAX).

All the questions in these categories were valuated using a 5-point Likert scale with 1—strongly disagree, 2-disagree, 3-neutral, 4-agree and 5-strongly agree. The questionnaire, along with the distribution of the received answers, is presented in Appendix A.

\subsection{Distribution}

The questionnaire was created and hosted using Google Forms. The form was available for filling in between 21 April 2020-16 June 2020. All the questions were marked as "mandatory", except for the control question, ensuring in this way that there were no empty values in the database. No incentives were given for participation.

A total of 711 valid questionnaires were filled in. Considering the control question, 16 persons did not add anything in the field associated with the question and they were eliminated from the sample. As a result, a total of 695 answers were kept for analysis, which is a reasonable number of observations [15,21-23,25-27,29-32,34,39].

\subsection{Questionnaire Analysis and Validation}

Data gathered through the questionnaire were analyzed and validated using IBM SPSS Amos 26.0.0 [56], by following the steps recommended in Byrne [57]. The structure of the components is presented in Figure 6.

Considering the structure in Figure 6 the values for the goodness-of-fit (GOF) indicators listed in Tables 2-4 were obtained.

Table 2 shows the values calculated for the minimum discrepancy weighted by the number of degrees of freedom (CMIN/DF). This value must be below the threshold of 5.00 [57,59]. In our case, CMIN/DF has the value of 5.282 which is higher than the threshold of 5.00 .

Table 2. Model fit summary-CMIN.

\begin{tabular}{cccccc}
\hline Model & NPAR & CMIN & DF & P & CMIN/DF \\
\hline Default model & 201 & 3702.720 & 701 & 0.000 & 5.282 \\
\hline Saturated model & 902 & 0.000 & 0 & & \\
\hline Independence model & 82 & 15576.565 & 820 & 0.000 & 18.996 \\
\hline
\end{tabular}


Comparative fit index (CFI), an incremental adjustment index, should exceed the threshold of 0.9 for the validation of the questionnaire [60]. In our case, the value of the index is 0.797 and suggests that an improvement model is needed. The values of the normed fit index (NFI), the incremental fit index (IFI) and the relative fit index (RFI) should exceed the threshold of 0.9. Considering the values in Table 3, it can be observed that the values for these indicators are below the imposed threshold value. According to Brown [61] and Byrne [57], additional analysis can be done by considering the values of the Tucker-Lewis index (TLI), which should be as close as possible to the value of 0.95 . The initial model has a value of this index of only 0.762 .

Table 3. Model fit summary-baseline comparisons.

\begin{tabular}{cccccc}
\hline Model & $\begin{array}{c}\text { NFI } \\
\text { Delta1 }\end{array}$ & $\begin{array}{c}\text { RFI } \\
\text { rho1 }\end{array}$ & $\begin{array}{c}\text { IFI } \\
\text { Delta2 }\end{array}$ & $\begin{array}{c}\text { TLI } \\
\text { rho2 }\end{array}$ & CFI \\
\hline Default model & 0.762 & 0.722 & 0.798 & 0.762 & 0.797 \\
\hline Saturated model & 1.000 & & 1.000 & & 1.000 \\
\hline Independence model & 0.000 & 0.000 & 0.000 & 0.000 & 0.000 \\
\hline
\end{tabular}

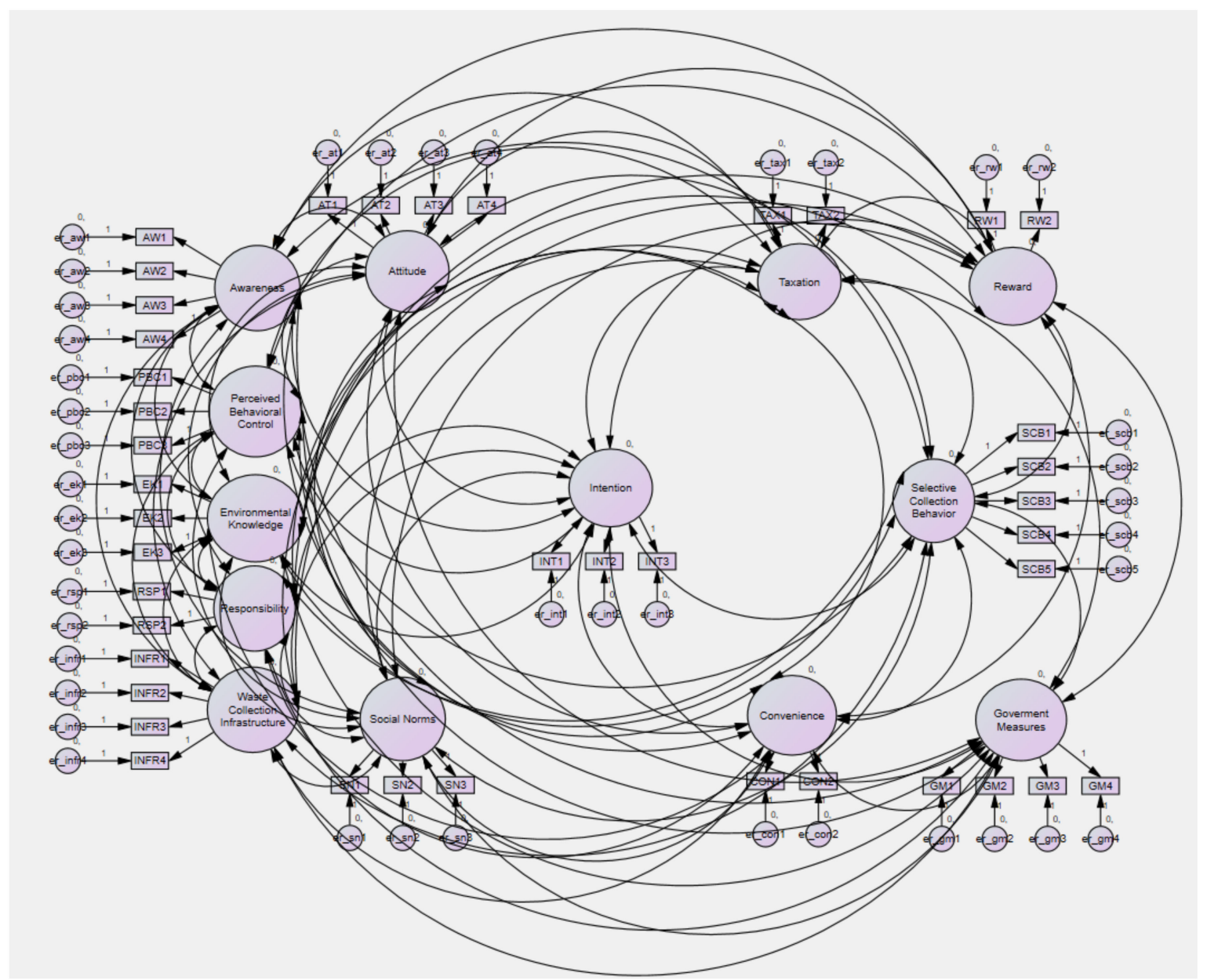

Figure 6. The individual components validation process-step 1. A confirmatory factor analysis [58] was used for questionnaire validation.

The last indicators in this category are the square mean root of the approximate errors (RMSEA) and the lower limit values (LO 90) and upper limit (HO 90) for a confidence interval of 90\%. Hu and Bentler [60] and Harrington [62] state that the RMSEA value must be less than 0.06 in order to indicate 
a good fit of the model. In our case, RMSEA records a value of 0.079 , which is above the mentioned threshold (Table 4). The confidence interval for RMSEA is between LO 90: 0.055 and HI 90: 0.081, and is within the threshold value of 0.085 imposed by Paswan [63].

Table 4. Model fit summary-RMSEA.

\begin{tabular}{ccccc}
\hline Model & RMSEA & LO 90 & HI 90 & PCLOSE \\
\hline Default model & 0.079 & 0.055 & 0.081 & 0.00 \\
\hline Independent model & 0.161 & 0.181 & 0.163 & 0.000 \\
\hline
\end{tabular}

Based on these results, along with the recorded values for the factor loadings, the structure of the model was improved as suggested by Sujata [37]. The new construct is presented in Figure 7.

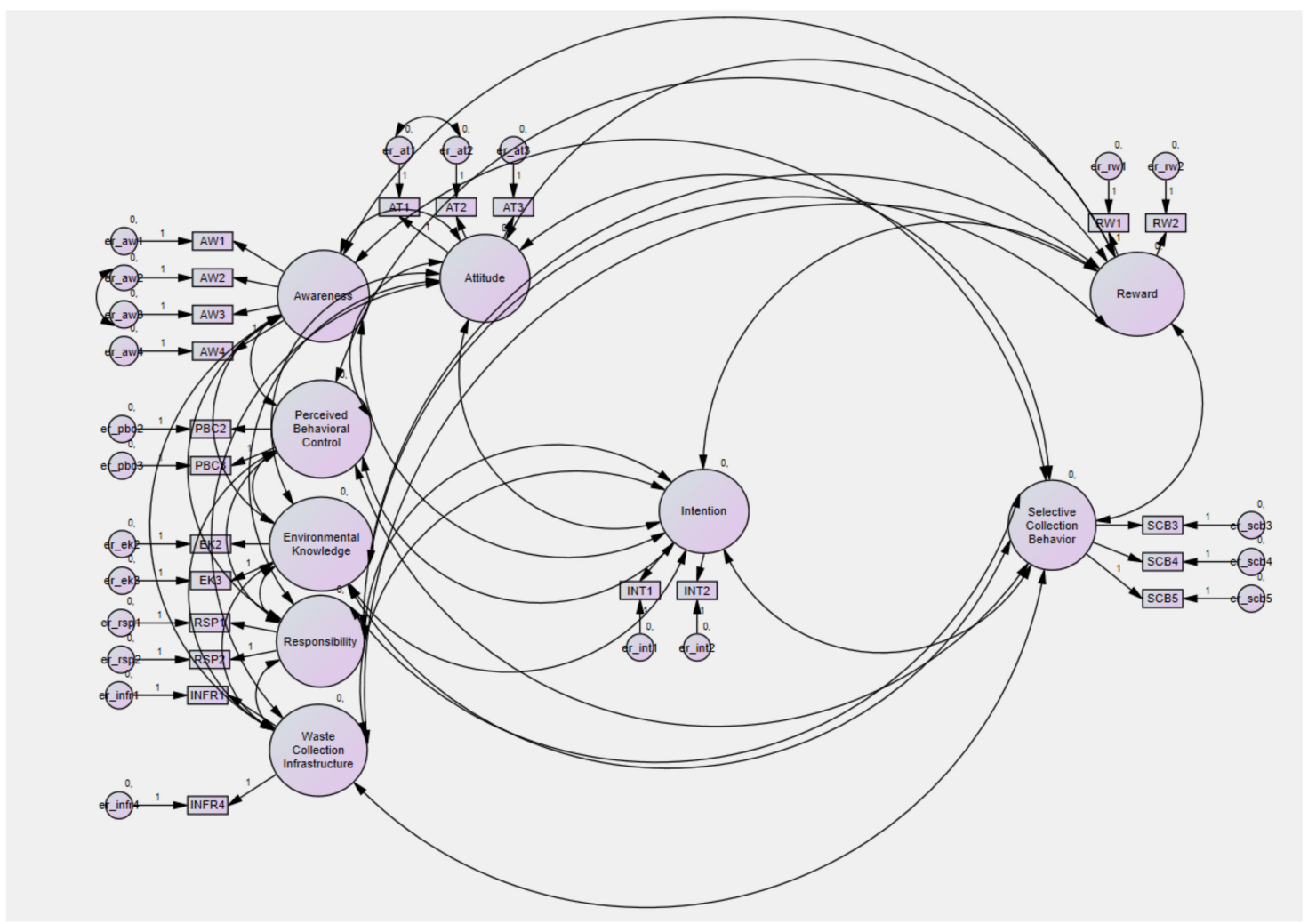

Figure 7. The individual components validation process—step 2.

A new validation was conducted and the data in Tables 5-7 were obtained.

Table 5 illustrates that the CMIN/DF is well below the imposed threshold value of 5.00, scoring 2.462. NFI, RFI, IFI and CFI exceed the threshold of 0.9 , so we can say that the model is also valid in terms of these indicators (Table 6). The TLI value exceeds the 0.95 threshold, supporting once more the validity of the model.

Table 5. Model fit summary-CMIN.

\begin{tabular}{cccccc}
\hline Model & NPAR & CMIN & DF & P & CMIN/DF \\
\hline Default model & 104 & 421.078 & 171 & 0.000 & 2.462 \\
\hline Saturated model & 275 & 0.000 & 0 & & \\
\hline Independent model & 44 & 8534.238 & 231 & 0.000 & 36.945 \\
\hline
\end{tabular}


Table 6. Model fit summary—Baseline comparisons.

\begin{tabular}{cccccc}
\hline Model & $\begin{array}{c}\text { NFI } \\
\text { Delta1 }\end{array}$ & $\begin{array}{c}\text { RFI } \\
\text { rho1 }\end{array}$ & $\begin{array}{c}\text { IFI } \\
\text { Delta2 }\end{array}$ & $\begin{array}{c}\text { TLI } \\
\text { rho2 }\end{array}$ & CFI \\
\hline Default model & 0.951 & 0.933 & 0.970 & 0.959 & 0.970 \\
\hline Saturated model & 1.000 & & 1.000 & & 1.000 \\
\hline Independent model & 0.000 & 0.000 & 0.000 & 0.000 & 0.000 \\
\hline
\end{tabular}

RMSEA is below the threshold of 0.06 (Table 7), which signifies a good model fit accordingly, while the limits of the confidence interval (LO90 $=0.040$ and Hi90 = 0.051) are below the imposed value of 0.085 suggested by Paswan [63]. Given the above, we can state that the validation of the model was successfully passed.

Table 7. Model fit summary-RMSEA.

\begin{tabular}{ccccc}
\hline Model & RMSEA & LO 90 & HI 90 & PCLOSE \\
\hline Default model & 0.046 & 0.040 & 0.051 & 0.886 \\
\hline Independent model & 0.228 & 0.223 & 0.232 & 0.000 \\
\hline
\end{tabular}

Considering the constructions validated above, the model in Figure 8 was proposed.

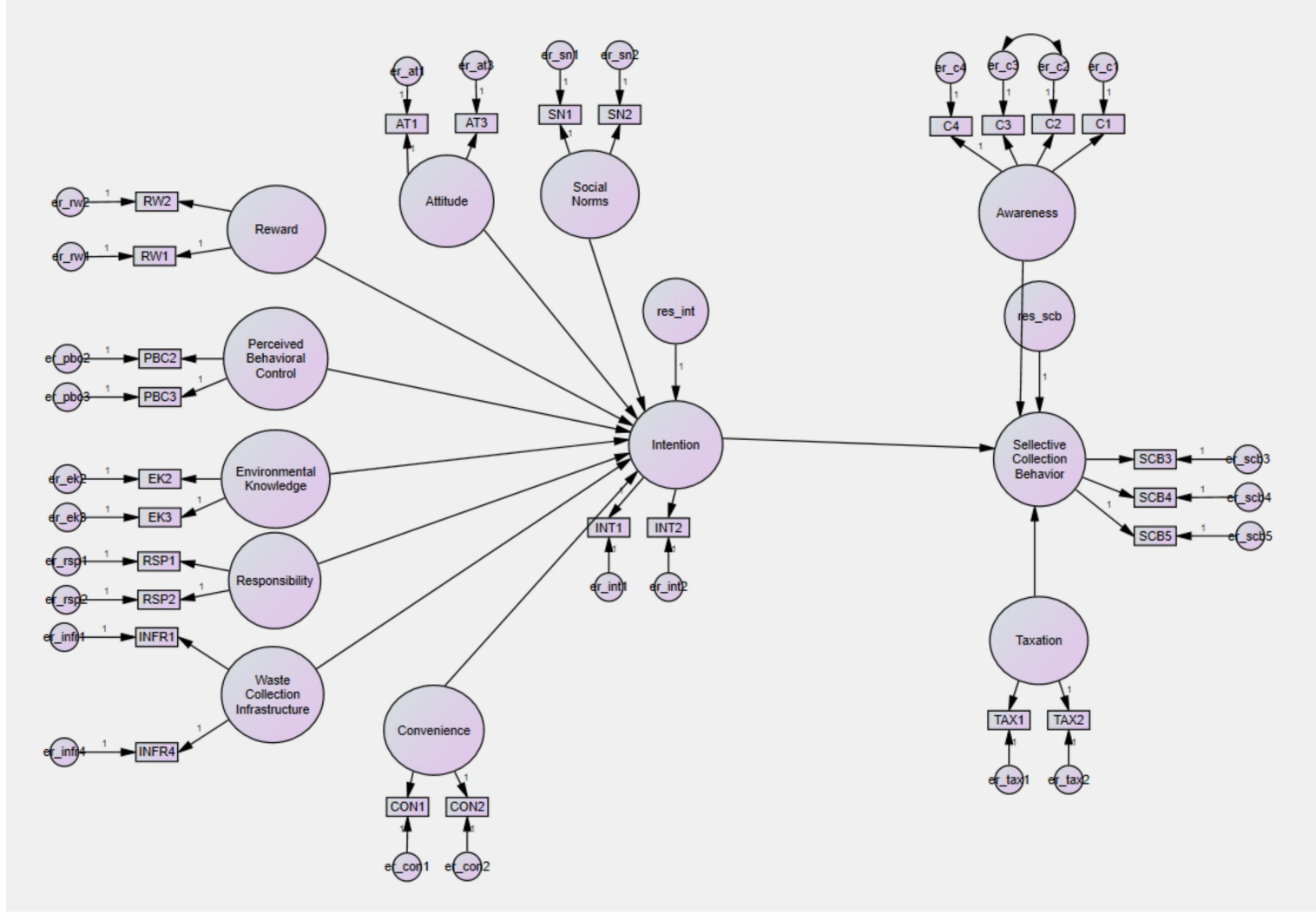

Figure 8. The model.

Construct reliability and convergent validity are tested using average variance extracted (AVE) and composite reliability (CR). The used software does not allow the automatic calculation of these 
indicators. We determined them manually using the factor loading listed Table 8 and the formulas provided by $[64,65]$ :

$$
\begin{gathered}
A V E=\frac{\sum_{i=1}^{n} \lambda_{i}^{2}}{n} \\
C R=\frac{\left(\sum_{i=1}^{n} \lambda_{i}^{2}\right)^{2}}{\left(\sum_{i=1}^{n} \lambda_{i}^{2}\right)^{2}+\sum_{i=1}^{n} \delta_{i}^{2}}
\end{gathered}
$$

where $\sum_{i=1}^{n} \lambda_{i}^{2}$ represents the sum of the square of the values recorded for each factor, presented above, and $\mathrm{n}$ is the number of factors in each group, and $\sum_{i=1}^{n} \delta_{i}$ represents the sum of the standardized variance of the error, which is determined as the difference between 1 and the feasibility of each element.

\begin{tabular}{|c|c|c|c|c|c|c|c|c|c|}
\hline & AT & AW & EK & RSP & PBC & INFR & RW & INT & SCB \\
\hline AT1 & 0.830 & & & & & & & & \\
\hline AT2 & 0.833 & & & & & & & & \\
\hline AT3 & 0.467 & & & & & & & & \\
\hline AW1 & & 0.849 & & & & & & & \\
\hline AW2 & & 0.702 & & & & & & & \\
\hline AW3 & & 0.740 & & & & & & & \\
\hline AW4 & & 0.809 & & & & & & & \\
\hline EK2 & & & 0.832 & & & & & & \\
\hline EK3 & & & 0.827 & & & & & & \\
\hline RSP1 & & & & 0.920 & & & & & \\
\hline RSP2 & & & & 0.810 & & & & & \\
\hline PBC2 & & & & & 0.992 & & & & \\
\hline РBC3 & & & & & 0.437 & & & & \\
\hline INFR1 & & & & & & 0.805 & & & \\
\hline INFR4 & & & & & & 0.791 & & & \\
\hline RW1 & & & & & & & 0.918 & & \\
\hline RW2 & & & & & & & 0.720 & & \\
\hline INT1 & & & & & & & & 0.878 & \\
\hline INT2 & & & & & & & & 0.655 & \\
\hline SCB3 & & & & & & & & & 0.743 \\
\hline SCB4 & & & & & & & & & 0.817 \\
\hline SCB5 & & & & & & & & & 0.712 \\
\hline AVE & 0.534 & 0.604 & 0.688 & 0.751 & 0.588 & 0.637 & 0.681 & 0.600 & 0.575 \\
\hline CR & 0.839 & 0.914 & 0.890 & 0.917 & 0.781 & 0.863 & 0.881 & 0.834 & 0.876 \\
\hline
\end{tabular}

Table 8. Standardized regression weights, average variance extracted (AVE) and construct reliability (CR).

Attitude (AT), Awareness (AW), Environmental Knowledge (EK), Responsibility (RSP), Perceived Behavioral Control (PBC), Waste Collection Infrastructure (INFR), Reward (RW), Intention (INT), Selective Collection Behavior (SCB).

The values for AVE and CR are listed in the last two rows of the table (marked with grey). As it can be seen from the table, the $C R$ values are higher than 0.7 for all variables considered in the analysis, which suggests good construct reliability. All the AVE values exceed the threshold of 0.5 , which signifies 
that the model has good convergent validity. Given the above, we can say that the proposed model meets the criteria of feasibility and convergent validity.

\subsection{Hypotheses}

The hypotheses to be tested are:

Hypothesis 1 (H1). The attitude towards selective collection has a positive impact on the intention of selective waste collection.

Hypothesis 2 (H2). The reward that consumers can receive when collecting selectively has a positive impact on the intention to selectively collect.

Hypothesis 3 (H3). Perceived behavioral control positively influences the intention of selective collection.

Hypothesis 4 (H4). Knowledge of the environment positively influences the intention of selective collection.

Hypothesis 5 (H5). Responsibility positively influences the intention of selective collection.

Hypothesis 6 (H6). The state/existence of the selective collection infrastructure positively influences the intention of selective collection.

Hypothesis 7 (H7). Awareness positively impacts selective collection behavior.

Hypothesis 8 (H8). Selective collection intention positively impacts selective collection behavior.

The considered hypotheses are summarized in Figure 9.

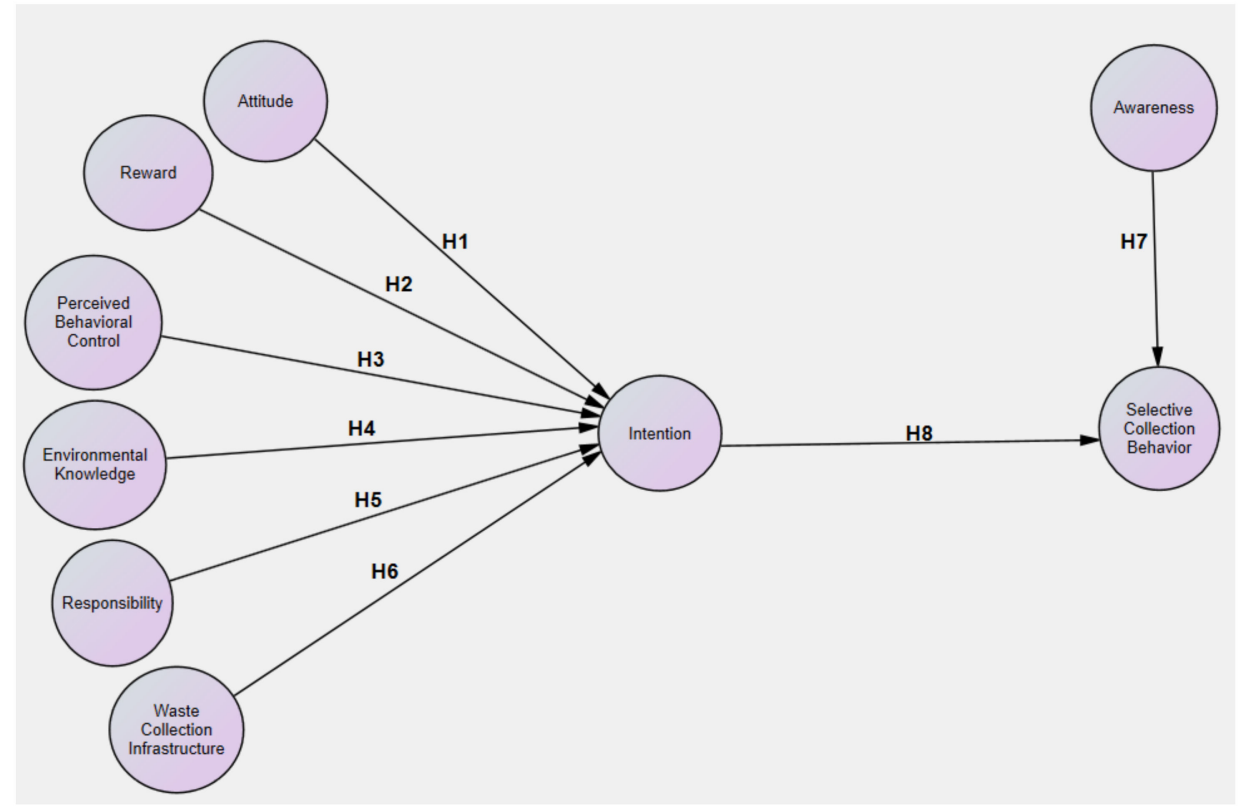

Figure 9. The hypotheses framework.

\section{Case Study}

\subsection{Demographic and Socio-Economic Characteristics}

The demographic and socio-economic characteristics of the respondents are presented in Table 9. 
Table 9. Demographic and socio-economic profile of respondents ( $\mathrm{n}=695$ persons).

\begin{tabular}{|c|c|c|c|}
\hline Demographic and Socio-Economic Variables & Group/Components & Frequency & Percentage \\
\hline \multirow{2}{*}{ Gender } & Female & 554 & $79.71 \%$ \\
\hline & Male & 141 & $20.29 \%$ \\
\hline \multirow{5}{*}{ Age } & $\leq 20$ & 89 & $12.80 \%$ \\
\hline & $21-30$ & 237 & $34.10 \%$ \\
\hline & $31-40$ & 234 & $36.67 \%$ \\
\hline & $41-50$ & 100 & $14.39 \%$ \\
\hline & $\geq 51$ & 35 & $5.04 \%$ \\
\hline \multirow{7}{*}{ Educational level } & Secondary education & 16 & $2.30 \%$ \\
\hline & High school education, lower cycle & 24 & $3.45 \%$ \\
\hline & High school education, upper cycle & 190 & $27.34 \%$ \\
\hline & Post-secondary education & 18 & $2.60 \%$ \\
\hline & Bachelor's degree & 223 & $32.09 \%$ \\
\hline & Master's degree & 202 & $29.07 \%$ \\
\hline & $\mathrm{PhD}$ & 22 & $3.15 \%$ \\
\hline \multirow{2}{*}{ Residential area } & Urban & 565 & $81.71 \%$ \\
\hline & Rural & 130 & $18.29 \%$ \\
\hline \multirow{3}{*}{ Marital status } & Single & 380 & $54.67 \%$ \\
\hline & Married & 284 & $40.87 \%$ \\
\hline & Divorced & 31 & $4.46 \%$ \\
\hline \multirow{6}{*}{ Occupation } & Student & 206 & $29.64 \%$ \\
\hline & Employed in the public sector & 80 & $11.51 \%$ \\
\hline & Employed in the private sector & 274 & $39.42 \%$ \\
\hline & Entrepreneur & 51 & $7.34 \%$ \\
\hline & Freelancer & 34 & $4.89 \%$ \\
\hline & Others & 50 & $7.20 \%$ \\
\hline \multirow{3}{*}{ Family size } & $1-2$ persons & 321 & $46.19 \%$ \\
\hline & $3-4$ persons & 317 & $45.61 \%$ \\
\hline & $\geq 5$ persons & 57 & $8.2 \%$ \\
\hline \multirow{6}{*}{ Income } & $\leq 280 €$ & 171 & $24.60 \%$ \\
\hline & $281-400 €$ & 73 & $10.50 \%$ \\
\hline & $401-750 €$ & 139 & $20.00 \%$ \\
\hline & $751-1000 €$ & 150 & $21.57 \%$ \\
\hline & $1001-1500 €$ & 85 & $12.22 \%$ \\
\hline & $>1500 €$ & 78 & $11.01 \%$ \\
\hline \multirow{5}{*}{ Number of years in e-waste recycling } & Do not practice & 196 & $28.20 \%$ \\
\hline & $\leq 1$ year & 166 & $23.88 \%$ \\
\hline & $2-3$ years & 202 & $29.06 \%$ \\
\hline & $4-5$ years & 60 & $8.64 \%$ \\
\hline & $\geq 6$ years & 71 & $10.22 \%$ \\
\hline \multirow{5}{*}{ Most frequently used social media } & Facebook & 430 & $61.87 \%$ \\
\hline & Twitter & 8 & $1.15 \%$ \\
\hline & Instagram & 222 & $31.95 \%$ \\
\hline & LinkedIn & 14 & $2.01 \%$ \\
\hline & Others & 21 & $3.02 \%$ \\
\hline
\end{tabular}


Out of the 695 respondents, $79.71 \%$ are women, while $20.29 \%$ are men. The structure of the respondents on age shows that most of the respondents belong to the 21-30 years old (34.10\%) and the $31-40$ years old categories (36.67\%). The residence of the respondents is predominantly urban, with a share of $81.29 \%$; the rest of the people come from rural areas $(18.71 \%)$. Regarding the occupation, it is observed that $29.64 \%$ of the respondents are students, and $39.42 \%$ are employed in the private sector. These two categories occupy a share of $69.06 \%$ of the total answers. The number of family members is $1-2$ people for $46.19 \%$ of respondents, $3-4$ people for $45.61 \%$ and more than 5 people for $8.2 \%$ of respondents. Monthly income was measured in the national currency and translated into euros. Among the respondents, $24.60 \%$ have a monthly income of less than $280 €$ (the minimum wage in the Romanian economy), 20\% have an income that falls between $751-1000 €, 21.57 \%$ marked an income between 1001-1500 $€$. Additionally, there are respondents who fall into the following categories of monthly income: $281-400 €(10.50 \%), 1001-1500 €(12.22 \%)$ and over $1500 €(11.01 \%)$.

Among the most used social networks, Facebook is the most popular platform, with $61.87 \%$ of respondents marking it as the most frequently used social platform. Facebook is followed by Instagram, which is marked as the most used platform by $31.95 \%$ of respondents. These two social networks are followed by LinkedIn (2.01\%) and Twitter (1.15\%). Additionally, 3.02\% of the respondents pointed out that they most frequently use another social network that is not found among those mentioned in the questionnaire.

\subsection{Selective Collection Behavior}

In the following, the answers received for the determinants considered in the paper will be discussed. The decision to provide an analysis related to the obtained results is in line with approaches in the literature. Depending on the situation, the authors have decided to present a complete analysis of the values of the variables or some cumulative results in terms of mean and standard deviation. Please consider the following papers for further reference: $[22,24,25,28,35,36,38,41]$. The purpose of analyzing the answers the respondents offered to questions is to shed light on the level of knowledge of the respondents related to each of the elements considered in the questionnaire and further analyzed using the structural equation model. We believe this analysis to be important as it provides more insight on the respondents' believes over the selected topics related to the selective collecting process. A similar analysis is performed by Byrne and $\mathrm{O}^{\prime}$ Regan [24].

\subsubsection{Attitude}

The answers to the questions corresponding to the variable that measures consumers' attitudes towards selective waste collection are highlighted in Figure 10.

Based on the answers, it was observed that, in general, respondents have a good opinion of the selective collection process.

A total of 533 respondents $(76.69 \%)$ expressed their total agreement on the benefit of selective collection at the level of the whole society, while only 6 people $(0.86 \%)$ expressed their disagreement and total disagreement.

Practicing selective collection contributes to the protection of the environment according to 659 participants $(94.82 \%)$ in the study, while only 9 of the respondents $(1.29 \%)$ expressed their disagreement or total disagreement.

A number of 494 respondents $(71.08 \%)$ considered that the practice of selective collection reduces the amount of waste they produce, 123 respondents $(17.70 \%)$ did not have an opinion on this statement, and 78 of the respondents $(11.22 \%)$ did not agree with this idea.

Also, 539 respondents $(77.55 \%)$ stated that they enjoyed participating in selective waste collection, 41 respondents marked (5.90\%) that were not interested in collecting selectively, while 115 people $(16.55 \%)$ did not have an opinion related to this issue. 


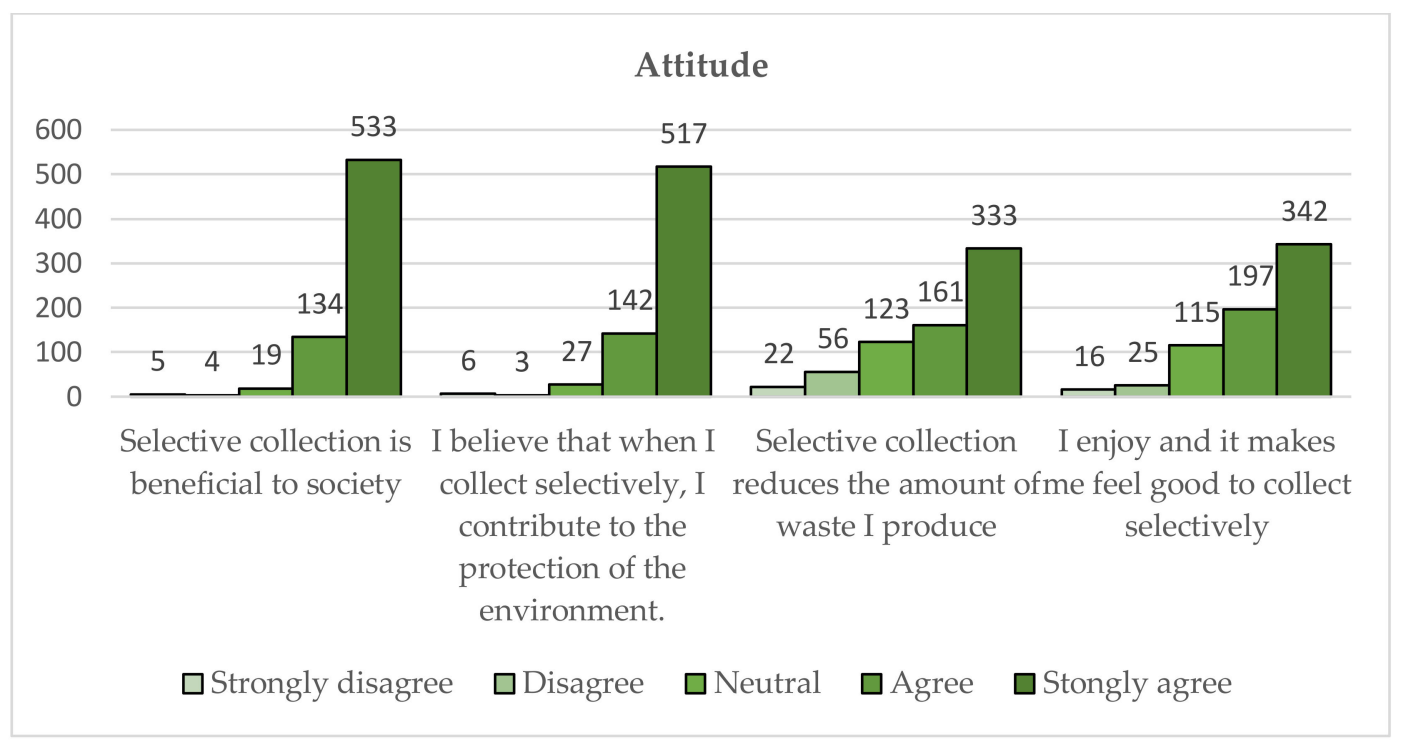

Figure 10. The distribution of the answers received for Attitude.

\subsubsection{Awareness}

The questions asked to determine the respondents' awareness of environmental issues had a positive result, most of the respondents being aware of their existence and magnitude.

Figure 11 shows that the vast majority of respondents, 658 (representing 94.68\%), said that they were aware of the benefits that selective collection has on the environment. On the other hand, only 12 respondents $(1.73 \%)$ stated they did not agree with this aspect, while 25 respondents $(3.60 \%)$ did not have any opinion on this idea.

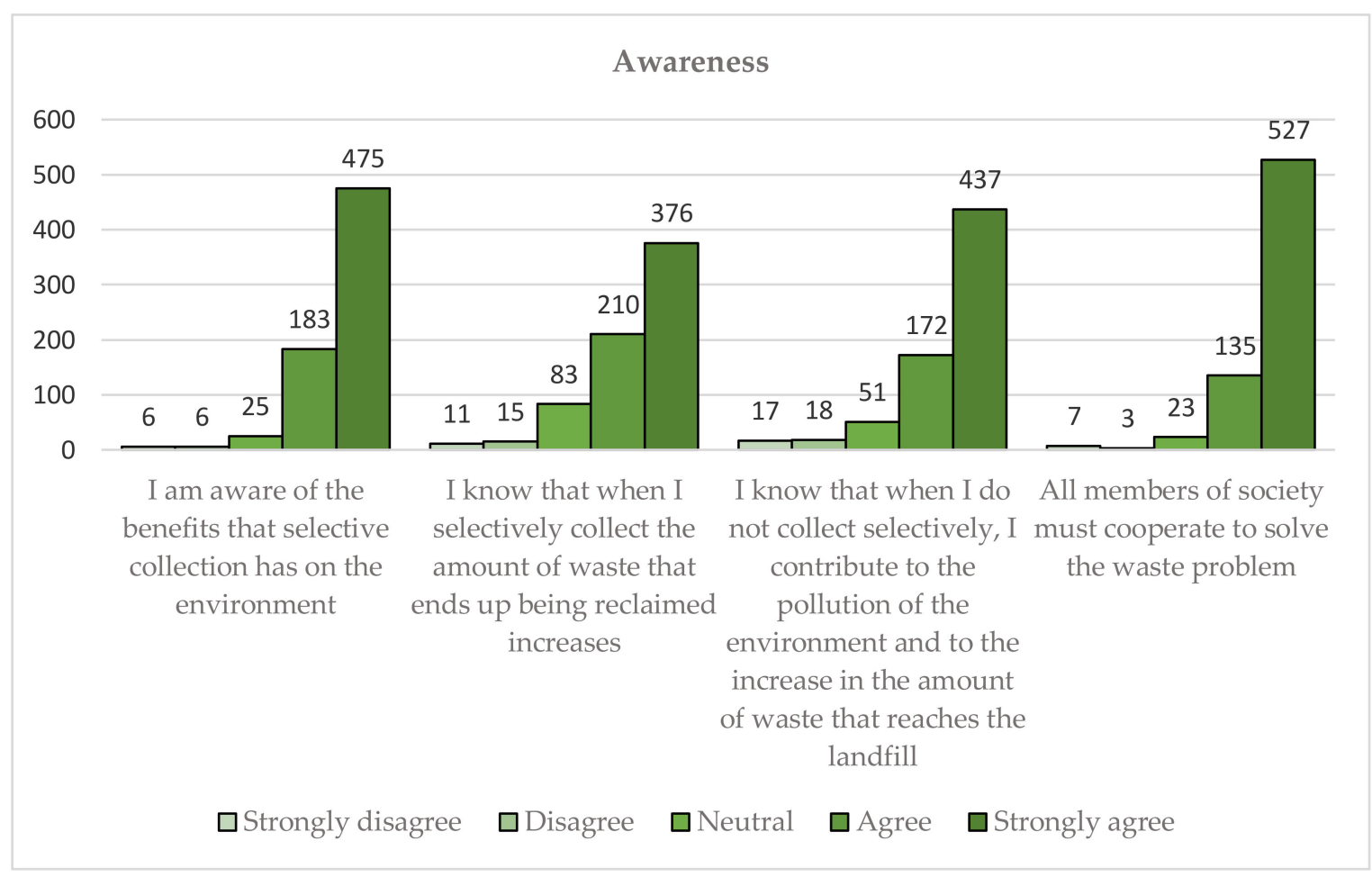

Figure 11. The distribution of the answers received for Awareness. 
Regarding the increase in the amount of waste that ends up being revalued, it is observed that 586 respondents $(84.32 \%)$ agree with this statement, while 26 disagree (3.74\%). Out of the respondents, $11.94 \%$ (represented by 83 respondents) had no particular opinion regarding this statement.

The vast majority of respondents (609 people), representing $87.63 \%$, were aware that when they do not collect selectively, they contribute to environmental pollution and increase the amount of waste that reaches the landfill. Only 35 of the respondents (5.04\%) stated that they did not agree with this fact, and 51 of the respondents $(7.34 \%)$ did not have any opinion on this issue.

The idea that all members of society must cooperate to solve the waste problem was approved by 662 of the respondents $(95.25 \%)$, on the other hand, 10 respondents $(1.44 \%)$ marked that they do not agree with this idea. Also, a number of 23 respondents (3.31\%) are neutral on this issue.

\subsubsection{Environmental Knowledge}

Given the statements made to determine the level of environmental knowledge of respondents, it turned out that many of them are correctly informed.

Thus, Figure 12 shows that 525 respondents $(75.54 \%)$ know how to selectively collect correctly and know the types of waste that can be recycled. There were also 45 respondents $(6.47 \%)$ who admitted that did not know how to collect selectively in a correct way, while 125 respondents (17.99\%) did not express their opinion.

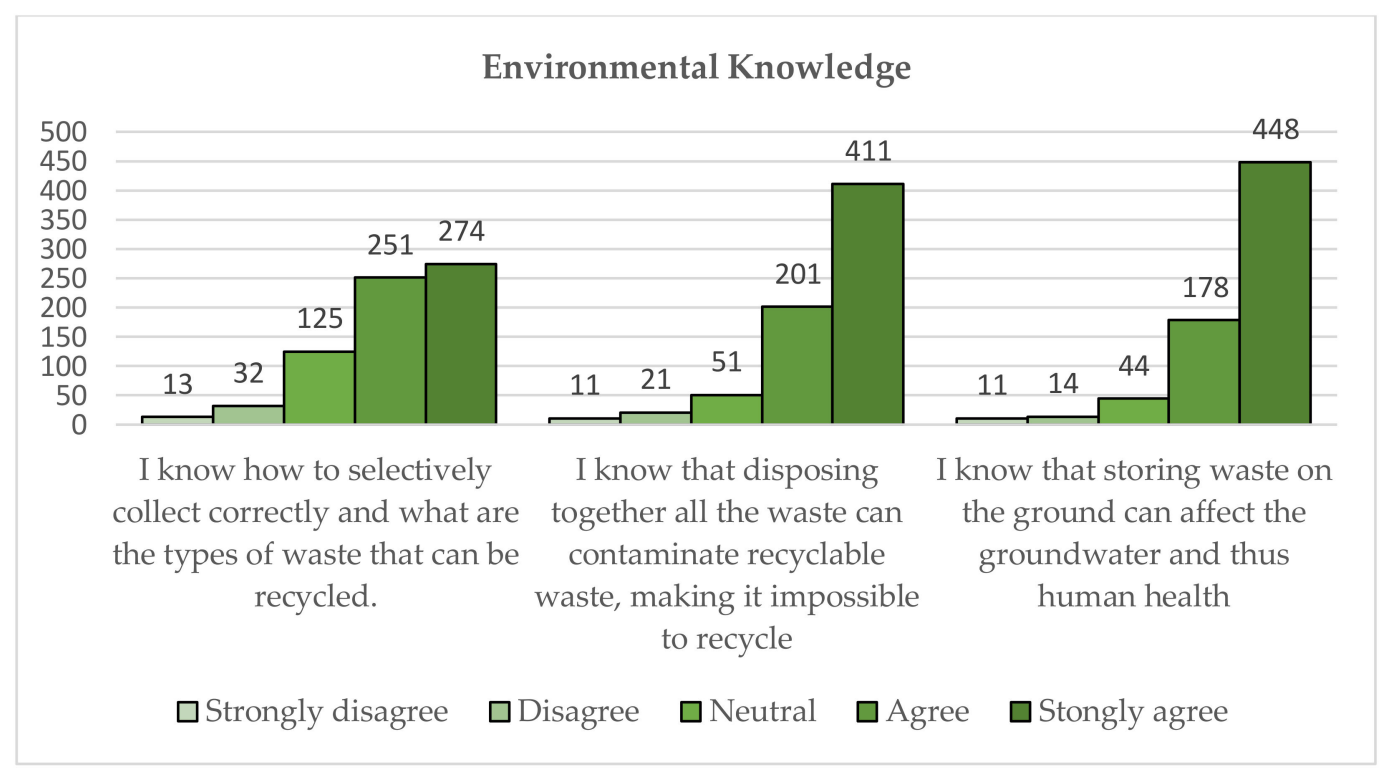

Figure 12. The distribution of the answers received for Environmental Knowledge.

At the same time, 612 people $(88.06 \%)$ knew that common waste storage can cause contamination of recyclable waste, making it impossible to recycle. This information was not available for 32 respondents $(4.60 \%)$, while 51 respondents $(7.34 \%)$ were neutral about this statement.

Regarding the idea that landfilling can affect the groundwater and thus human health, it is noted that 626 of the participants in the questionnaire $(90.07 \%)$ had this information and agreed with this aspect, while 25 respondents (3.60\%) did not agree with this idea. At the same time, 44 of the participants $(6.33 \%)$ did not express any opinion on this issue.

\subsubsection{Waste Collecting Infrastructure}

Regarding the selective collection infrastructure, as shown in Figure 13, 649 respondents (93.38\%) agreed that the collection centers must be properly managed, a smaller group of 11 respondents $(1.58 \%)$ did not agree with this aspect, while 35 respondents (5.04\%) did not express their opinion. 


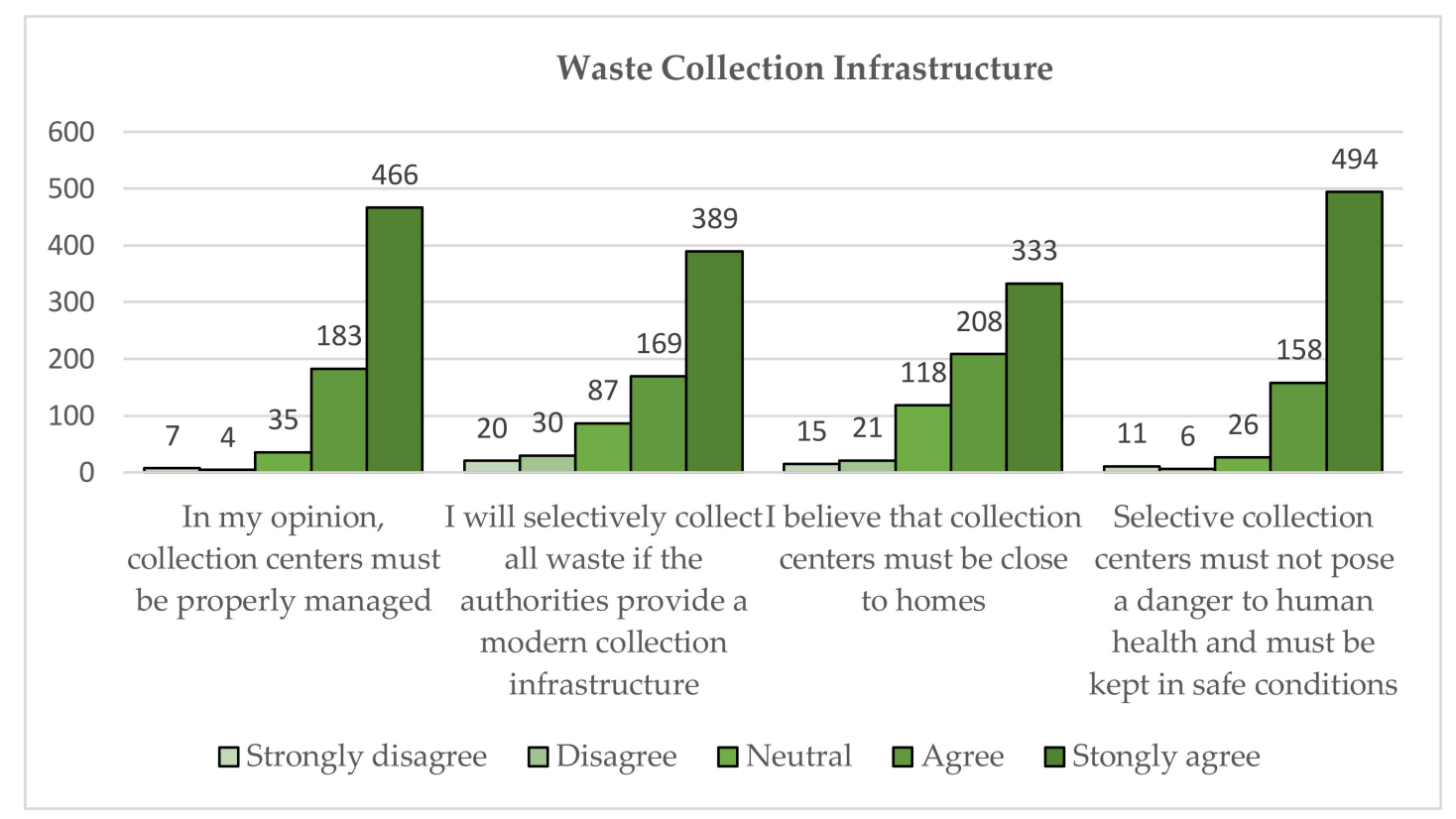

Figure 13. The distribution of the answers received for Waste Collection Infrastructure.

A total of 558 respondents $(80.29 \%)$ claimed that they would selectively collect all waste if the authorities provided a modern collection infrastructure. Additionally, 50 respondents $(7.19 \%)$ stated that they would not collect selectively even under these conditions in which the collection infrastructure would be modernized, while 87 participants in the questionnaire $(12.52 \%)$ were neutral about this idea.

The idea that collection centers should be close to homes was supported by 541 respondents $(77.84 \%)$, while only 36 respondents $(5.18 \%)$ did not agree with this idea. At the same time, 118 respondents $(16.98 \%)$ were neutral in this regard.

Of the total number of 695 participants in the questionnaire, $652(93.81 \%)$ argued that selective collection centers should not be a danger to human health and should be kept in safe conditions. A small group of 17 people $(2.45 \%)$ did not agree that selective collection centers should be kept in good health, while 26 respondents (3.74\%) had no opinion on this issue.

\subsubsection{Perceived Behavioral Control}

Perceived behavioral control was measured by responses to three questions related to the difficulty of selective collection, respondents' knowledge regarding recycling and the involvement of authorities in selective collection. A summary of the answers received for each question is provided in Appendix B.

More than half of the respondents, $60.57 \%$, indicated that they do not consider selective collection a difficult activity. On the other hand, $28.06 \%$ find selective collection to be a difficult activity. Of the total number of respondents, $22.59 \%$ did not express any opinion on the difficulty of the selective collection activity.

Furthermore, regarding the involvement of the authorities in selective collection, $56.83 \%$ of the respondents disagreed with the idea that the authorities provide enough containers to collect selectively. Of the respondents, $24.75 \%$ agreed that the provided containers were enough for ensuring a proper selective collection process.

\subsubsection{Selective Collection Behavior}

Regarding the behavior of selective collecting, the participants in the questionnaire answered five questions related to this issue. The results are summarized in Appendix B.

Half of the respondents agreed that they separate all the waste they produce, while $23.31 \%$ of them disagreed with this statement, resulting in the knowledge that they do not separate the waste produced. At the same time, $67.63 \%$ of the respondents did not agree with the statement that they do 
not selectively collect and throw all waste in the same container, while $18.99 \%$ of them indicated that they do throw all waste in the same container.

\subsubsection{Intention}

Respondents' intention to collect selectively was analyzed through three questions. A summary of the received answers is provided in Appendix B.

Overall, the participants' answers to the questions belonging to this category were positive, with more than half of them intending to engage in selective collection. Thus, $74.82 \%$ of the respondents stated that they intend to get involved in this activity, even if it would not always be easy for them to do so, while $5.61 \%$ of the participants stated that they did not intend to do so. Furthermore, $19.57 \%$ of respondents did not express any opinion on this issue.

Regarding the purchase of products whose packaging is $100 \%$ recyclable, $43.31 \%$ of respondents expressed their intention to purchase this type of product, $21.44 \%$ of them did not agree with this aspect, and $35.25 \%$ of participants did not express their opinion on this idea (Appendix B).

\subsubsection{Responsibility}

Regarding the awareness of the responsibility consumers have, the respondents mainly felt responsible for the amount of waste they generate, and which could be recycled, as well as for increasing the amount of waste that could be recovered (Appendix B).

Therefore, $86.18 \%$ of respondents agreed that they feel responsible for collecting selectively in order to increase the amount of waste that could be recovered, while $3.74 \%$ of respondents said they did not feel responsible for this action. Also, $10 \%$ of the participants did not express their opinion on this issue.

Regarding the amount of waste that could be recycled, but instead reaches the landfill, $85.18 \%$ of respondents feel responsible for it, being aware that their actions could reduce this amount of waste that is not capitalized on. On the other hand, $4.32 \%$ of respondents did not feel responsible for the waste that ends up in landfill, and $10.50 \%$ did not have an opinion on this issue (Appendix B).

\subsubsection{Reward}

In general, people are encouraged to engage in a particular activity when they receive rewards. In order to determine whether this is also the case with regard to selective collection, the answers of the questionnaire participants to the two questions related to this topic were analyzed (Appendix B).

Thus, $39.71 \%$ of respondents did not agree that they would collect selectively if selective collection programs involved a financial reward, and $30.94 \%$ of them claimed that a reward would stimulate them to collect selectively.

At the same time, $54.24 \%$ of respondents agreed that they are more likely to collect selectively if they received a discount on the supermarket tax receipt for returned packaging. However, $24.31 \%$ of respondents did not agree with this issue, and $21.44 \%$ did not express any opinion on this idea (Appendix B).

\subsubsection{Convenience, Government Measures, Social Norms and Taxation}

The answers received regarding these categories are presented in Appendix B. We have decided not to discuss them in the body of the paper as these constructions do not belong to the model nor to the hypotheses to be tested.

\subsection{Structural Model Results}

Based on the research hypotheses, the structural model was run. Table 10 summarizes the decision taken with regard to each of the formulated hypotheses. 
Table 10. Hypotheses test results.

\begin{tabular}{ccc}
\hline Hypotheses & Relationship & Decision \\
\hline H1 & Attitude $\rightarrow$ Intention & Not supported \\
\hline H2 & Reward $\rightarrow$ Intention & Supported $^{+}$ \\
\hline H3 & Perceived Behavioral Control $\rightarrow$ Intention & Supported $^{* * *}$ \\
\hline H4 & Environment Knowledge $\rightarrow$ Intention & Not supported $^{*}$ \\
\hline H5 & Responsibility $\rightarrow$ Intention & Supported $^{* * *}$ \\
\hline H6 & Waste Collection Infrastructure $\rightarrow$ Intention & Supported $^{* * *}$ \\
\hline H7 & Awareness $\rightarrow$ Selective Collection Behavior & Supported $^{* *}$ \\
\hline H8 & Intention $\rightarrow$ Selective Collection Behavior $^{* *}$ & Supported $^{* * *}$ \\
\hline & Note: ${ }^{+} p<0.10,{ }^{* *} p<0.01,{ }^{* * *} p<0.001$. &
\end{tabular}

As can be seen in Table 10, from the 8 hypotheses we considered, 6 hypotheses were validated at different levels of significance. The variables that had a significant and positive impact on selective collection Intention are: Perceived Behavioral Control, Responsibility, Selective Collection Infrastructure. Two of the determinants, represented by Attitude and Environmental Knowledge, did not receive significant values in order to be validated.

The Selective Collection Behavior is positively influenced by both considered variables, namely Awareness and Intention in the case of the Romanian participants. Based on the answers received for Awareness, it can be stated that most of the respondents have the necessary knowledge regarding the importance of cooperation among the members of society for solving the waste issue. Even more, as the influence of Awareness on the selective collecting behavior is acknowledged as significant, increasing the population's awareness will generate a positive outcome for the overall collective selection process.

Considering the literature, we can observe that the positive impact of Reward has also been demonstrated in the research conducted by Wang [40] and Amini [23].

Considering the results, it can be observed that Responsibility has a positive and significant impact on Intention, similar to the study conducted in Romania regarding the e-waste recycling behavior [42].

Another validated result, represented by Waste Collection Infrastructure's positive impact on Intention, is in line with the research conducted by Nduneseokwu et al. [31].

Perceived Behavioral Control has a positive and significant impact on the Intention of selective collection and it is in line with studies by Yuan [29], Boldero [13], Wang et al. [40], Mahmud and Osman [17], Valle et al. [16], Halder and Singh [43].

Both hypotheses regarding the variables that influence behavior were validated at a high level of significance. Even in this case, the results are in line with the ones from the literature in which Awareness has been shown to have a significant and positive impact on Selective Collection Behavior as demonstrated in the study conducted by Nguyen [39], while the Intention of selective collection has been determined to have a significant impact on Behavior, as highlighted in Sujata et al. [37], Delcea et al. [42] and Strydom [36].

The "not supported" hypotheses are those regarding the positive impact of Attitude and Environment Knowledge on the Intention of selective collection. Considering the cumulative answers to the questions included in the three constructions regarding Environmental Knowledge, Attitude and Intention, it can be observed that most of the respondents marked a strong knowledge related to how storing waste on the ground can affect groundwater and human health, and that storing waste in an improper way can lead to the impossibility of recycling the waste; however, they marked a large amount of answers in the "neutral" area when asked about their intention to actively participate in the selective collection initiative or their intention to buy products with $100 \%$ recyclable package. The same situation happened even in the Attitude case. Even though the attitude score relative overall good marks for the first two questions, the last two questions provided a lot of neutral answers related 
to the feeling the respondents have as a result of the selective collecting process or to the reduction that selective collection provides in terms of produced waste.

As the female-male respondent ratio was unbalanced in favor of the females participating in the study, further analysis was conducted by dividing the respondents in two groups based on their gender. With these two groups, the structural model was run for testing the eight hypotheses. The results in Table 11 were obtained.

Table 11. Hypotheses test results based on gender.

\begin{tabular}{cccc}
\hline \multirow{2}{*}{ Hypotheses } & Relationship & \multicolumn{2}{c}{ Gender } \\
\cline { 3 - 4 } & Attitude $\rightarrow$ Intention & Females & Males \\
\hline H1 & Reward $\rightarrow$ Intention & Supported $^{+}$ & Supported $^{*}$ \\
\hline H3 & Perceived Behavioral Control $\rightarrow$ Intention & Supported $^{* * *}$ & Supported $^{* * *}$ \\
\hline H4 & Environment Knowledge $\rightarrow$ Intention & Not supported $^{*}$ & Not supported $^{* *}$ \\
\hline H5 & Responsibility $\rightarrow$ Intention & Supported $^{* *}$ & Supported $^{* * *}$ \\
\hline H6 & Waste Collection Infrastructure $\rightarrow$ Intention & Supported $^{* * *}$ & Supported $^{* * *}$ \\
\hline H7 & Awareness $\rightarrow$ Selective Collection Behavior & Supported $^{* *}$ & Supported $^{*}$ \\
\hline H8 & Intention $\rightarrow$ Selective Collection Behavior & Supported $^{* * *}$ & Supported $^{* * *}$ \\
\hline
\end{tabular}

Based on the data in Table 11, small differences among genders were observed for the $\mathrm{H} 2$ and H7 hypotheses. For both involved influencing factors, namely Awareness and Reward, it was determined that the significance degree is decreased for Awareness and increased for Reward in the case of the males compared to the females. As a result, it can be stated that the positive relation between Reward and Intention is stronger in the case of males. Looking closer at the answers offered by the males respondents, it can be seen that the Reward was regarded more as a determining factor than in the case of females; this might be due to a more practical approach men can have over the income and earnings. On the other hand, as females are more likely to engage in the households' domestic activities, it is possible that the Reward to be seen as a less important factor. On the other hand, the relationship among Awareness and Selective Collection Behavior has a smaller significance degree, which might be also due to the fact that males are less involved in the household activities. This observation is in line with the study conducted by Arcury [66].

Considering the results in Table 11, it can be stated that no significant difference is reported based on the respondents gender, with both males and females presenting a positive relationship among the considered variables, except for Attitude and Environment Knowledge where no conclusion can be made.

\section{Conclusions}

The present paper tries to analyze the determinants for the waste selective behavior in the case of Romanian citizens. Based on the literature, a series of possible variables were identified and a questionnaire was created in order to extract the variables' influence on selective collection intention and behavior.

As a result of the questionnaire validation process, nine variables remained in the study for which eight hypotheses have been tested.

After the hypothesis testing process, six of the formulated hypotheses were supported at different significance levels. Among the most influencing factors for the consumers' intention to engage in selective waste collection, one can name the perceived behavioral control, reward, responsibility and waste collection infrastructure. 
Considering the determinants for the selective waste collection behavior, namely the intention and awareness, one can identify some of the steps to be taken in order to increase the consumers' participation in selective collection actions.

As a result, boosting the consumers' influence by applying proper reward policies or providing adequate waste collection infrastructure is determined to further have a positive and significant influence on the outcome, represented by the consumers' enhanced engagement in selective waste collection. Nevertheless, creating promotion campaigns through which the consumers' responsibility is enhanced can produce a positive outcome on the consumers' behavior. Considering the literature, it has been observed that awareness campaigns have a moderate influence on the improvement of the separate collection rates [67]. As the respondents signaled the need for a more modern selective collection infrastructure, and given the influence of its presence on the selective collection behavior, decision-makers can consider allocating more resources to such activities. Furthermore, offering the proper means that would ease the selective collection process and create selective collection centers that are close to the residential areas might lead to a positive outcome.

Being aware of the characteristics and the incentives the consumers consider when engaging in selective collection behavior, the companies can re-think their business approach and can try to build a brand identity more oriented towards supporting the green and environmental protective activities [68].

The study has limitations related to the size of the sample and to the fact that the respondents had the needed skills to fill in a questionnaire in an online environment.

Further development of the study includes extracting the levels of the reward that would motivate the consumers to engage in such activities along with the distances related to what the respondents believe as being a reasonable distance to selective collection bins. Beside these two elements, other characteristics related to the selective collection infrastructure that might be considered by the consumers when deciding to collect selectively the waste can be extracted and included in an agent-based model. Based on this model, different scenarios can be simulated in order to assist the decision makers in substantiating their decisions and actions, with would result in stimulating consumers' participation in selective waste collection.

Author Contributions: Conceptualization, A.-I.J. and C.D.; data curation, A.-I.J., C.D. and C.I.; formal analysis, A.-I.J. and C.D.; investigation, A.-I.J. and C.I.; methodology, C.D. and C.I.; software, A.-I.J. and C.D.; supervision, C.D.; validation, A.-I.J. and C.I.; visualization, A.-I.J. and C.I.; writing-original draft, A.-I.J. and C.D.; writing-review and editing, C.I. All authors have read and agreed to the published version of the manuscript.

Funding: This work received no funding.

Conflicts of Interest: The authors declare no conflict of interest.

Appendix A Research Questionnaire

Table A1. The questionnaire used in research.

\begin{tabular}{|c|c|c|c|c|c|c|c|}
\hline Issue & Acronym & Questions & 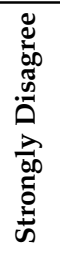 & 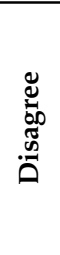 & \begin{tabular}{l}
$\bar{\Xi}$ \\
\multirow{\Xi}{\Xi}{} \\
Z
\end{tabular} & 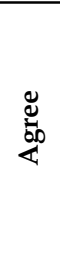 & 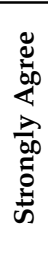 \\
\hline \multirow{4}{*}{ Attitude } & \multirow{4}{*}{ AT } & Selective collection is beneficial to society. (AT1) & $\square$ & $\square$ & $\square$ & $\square$ & $\square$ \\
\hline & & $\begin{array}{l}\text { I believe that when I collect selectively, I contribute to the } \\
\text { protection of the environment. (AT2) }\end{array}$ & $\square$ & $\square$ & $\square$ & $\square$ & $\square$ \\
\hline & & $\begin{array}{l}\text { Selective collection reduces the amount of waste I } \\
\text { produce. (AT3) }\end{array}$ & $\square$ & $\square$ & $\square$ & $\square$ & $\square$ \\
\hline & & I enjoy and it makes me feel good to collect selectively. (AT4) & 口 & 口 & 口 & $\square$ & $\square$ \\
\hline
\end{tabular}


Table A1. Cont.

\begin{tabular}{|c|c|c|c|c|c|c|c|}
\hline Issue & Acronym & Questions & 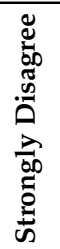 & 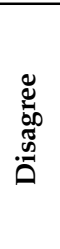 & 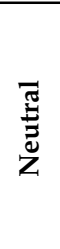 & 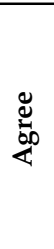 & 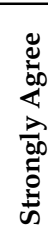 \\
\hline \multirow{4}{*}{ Awareness } & \multirow{4}{*}{ AW } & $\begin{array}{c}\text { I am aware of the benefits that selective collection has on the } \\
\text { environment. (AW1) }\end{array}$ & $\square$ & $\square$ & $\square$ & $\square$ & $\square$ \\
\hline & & $\begin{array}{l}\text { I know that when I collect selectively, the amount of waste that } \\
\text { ends up being reclaimed increases. (AW2) }\end{array}$ & $\square$ & $\square$ & $\square$ & $\square$ & $\square$ \\
\hline & & $\begin{array}{l}\text { I know that when I do not collect selectively, I contribute to the } \\
\text { pollution of the environment and to the increase in the amount } \\
\text { of waste that reaches the landfill. (AW3) }\end{array}$ & $\square$ & $\square$ & $\square$ & $\square$ & $\square$ \\
\hline & & $\begin{array}{l}\text { All members of society must cooperate to solve the waste } \\
\text { problem. (AW4) }\end{array}$ & $\square$ & $\square$ & $\square$ & $\square$ & $\square$ \\
\hline \multirow{3}{*}{$\begin{array}{l}\text { Perceived } \\
\text { Behavioral } \\
\text { Control }\end{array}$} & \multirow{3}{*}{ РBC } & For me, selective collection is a difficult activity. (PCB1) & $\square$ & $\square$ & $\square$ & $\square$ & $\square$ \\
\hline & & $\begin{array}{l}\text { I know where to dispose the waste that I have selectively } \\
\text { collected so that it can be recycled. (PCB2) }\end{array}$ & $\square$ & $\square$ & $\square$ & $\square$ & $\square$ \\
\hline & & $\begin{array}{l}\text { The authorities provide enough containers to collect } \\
\text { selectively. (PCB3) }\end{array}$ & $\square$ & $\square$ & $\square$ & $\square$ & $\square$ \\
\hline \multirow{2}{*}{ Convenience } & \multirow{2}{*}{$\mathrm{CON}$} & $\begin{array}{l}\text { Collecting selectively involves allocating the necessary space in } \\
\text { the house. (CON1) }\end{array}$ & $\square$ & $\square$ & $\square$ & $\square$ & $\square$ \\
\hline & & $\begin{array}{l}\text { Selective collection requires time that I cannot allocate to this } \\
\text { activity. (CON2) }\end{array}$ & $\square$ & $\square$ & $\square$ & $\square$ & $\square$ \\
\hline \multirow{3}{*}{$\begin{array}{l}\text { Environmental } \\
\text { Knowledge }\end{array}$} & \multirow{3}{*}{ EK } & $\begin{array}{c}\text { I know how to selectively collect correctly and what are the } \\
\text { types of waste that can be recycled. (EK1) }\end{array}$ & $\square$ & $\square$ & $\square$ & $\square$ & $\square$ \\
\hline & & $\begin{array}{l}\text { I know that disposing of all the waste together can contaminate } \\
\text { recyclable waste, making it impossible to recycle. (EK2) }\end{array}$ & $\square$ & $\square$ & $\square$ & $\square$ & $\square$ \\
\hline & & $\begin{array}{l}\text { I know that storing waste on the ground can affect the } \\
\text { groundwater and thus human health. (EK3) }\end{array}$ & $\square$ & $\square$ & $\square$ & $\square$ & $\square$ \\
\hline \multirow{5}{*}{$\begin{array}{l}\text { Selective } \\
\text { Collection } \\
\text { Behavior }\end{array}$} & \multirow{5}{*}{ SCB } & I separate all the waste I produce. (SCB1) & $\square$ & $\square$ & $\square$ & $\square$ & $\square$ \\
\hline & & $\begin{array}{l}\text { I do not collect selectively; I throw all the waste in the same } \\
\text { container. (SCB2) }\end{array}$ & $\square$ & $\square$ & $\square$ & $\square$ & $\square$ \\
\hline & & I selectively collect the paper. (SCB3) & $\square$ & $\square$ & $\square$ & $\square$ & $\square$ \\
\hline & & I selectively collect plastic items. (SCB4) & $\square$ & $\square$ & $\square$ & $\square$ & $\square$ \\
\hline & & I selectively collect household appliances. (SCB5) & $\square$ & $\square$ & $\square$ & $\square$ & $\square$ \\
\hline \multirow{4}{*}{$\begin{array}{l}\text { Government } \\
\text { Measures }\end{array}$} & \multirow{4}{*}{ GM } & $\begin{array}{c}\text { If selective collection were mandatory, I would start collecting } \\
\text { selectively. (GM1) }\end{array}$ & $\square$ & $\square$ & $\square$ & $\square$ & $\square$ \\
\hline & & $\begin{array}{l}\text { If the trash that is not selectively collected wouldn't be } \\
\text { collected, I would start collecting selectively. (GM2) }\end{array}$ & $\square$ & $\square$ & $\square$ & $\square$ & $\square$ \\
\hline & & $\begin{array}{l}\text { I believe that the application of strict laws on selective } \\
\text { collection would lead people to engage in this process } \\
\text { more. (GM3) }\end{array}$ & $\square$ & $\square$ & $\square$ & $\square$ & $\square$ \\
\hline & & $\begin{array}{c}\text { If the sanitation fee were lower for the households who are } \\
\text { selectively collecting, more households would engage in this } \\
\text { activity. (GM4) }\end{array}$ & $\square$ & $\square$ & $\square$ & $\square$ & $\square$ \\
\hline \multirow{4}{*}{ Intention } & \multirow{4}{*}{ INT } & $\begin{array}{l}\text { I aim to selectively collect all the waste I produce, even if it is } \\
\text { not always easy for me. (INT1) }\end{array}$ & $\square$ & $\square$ & $\square$ & $\square$ & $\square$ \\
\hline & & $\begin{array}{l}\text { I intend to actively participate in the selective collection } \\
\text { initiatives promoted on social media. (INT2) }\end{array}$ & $\square$ & $\square$ & $\square$ & $\square$ & $\square$ \\
\hline & & $\begin{array}{l}\text { I intend to buy only products whose packaging is } 100 \% \\
\text { recyclable. (INT3) }\end{array}$ & $\square$ & $\square$ & $\square$ & $\square$ & $\square$ \\
\hline & & $\begin{array}{l}\text { I intend to selectively collect all the waste I produce and reduce } \\
\text { the amount of waste I generate annually. (INT4) }\end{array}$ & $\square$ & $\square$ & $\square$ & $\square$ & $\square$ \\
\hline
\end{tabular}


Table A1. Cont.

\begin{tabular}{|c|c|c|c|c|c|c|c|}
\hline Issue & Acronym & Questions & 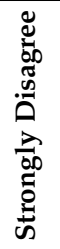 & 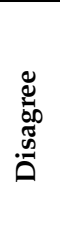 & 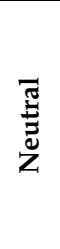 & 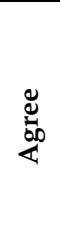 & 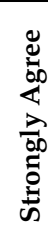 \\
\hline \multirow{4}{*}{$\begin{array}{l}\text { Waste } \\
\text { Collection } \\
\text { Infrastructure }\end{array}$} & \multirow{4}{*}{ INFR } & $\begin{array}{l}\text { In my opinion, collection centers must be properly } \\
\text { managed. (INFR1) }\end{array}$ & 口 & $\square$ & $\square$ & 口 & 口 \\
\hline & & $\begin{array}{l}\text { I will selectively collect all waste if the authorities provided a } \\
\text { modern collection infrastructure. (INFR2) }\end{array}$ & $\square$ & $\square$ & $\square$ & $\square$ & $\square$ \\
\hline & & I believe that collection centers must be close to homes. (INFR3) & $\square$ & $\square$ & $\square$ & $\square$ & $\square$ \\
\hline & & $\begin{array}{l}\text { Selective collection centers must not pose a danger to human } \\
\text { health and must be kept in safe conditions. (INFR4) }\end{array}$ & $\square$ & $\square$ & 口 & 口 & $\square$ \\
\hline \multirow{3}{*}{ Social Norms } & \multirow{3}{*}{ SN } & $\begin{array}{l}\text { All the people who matter to me (family, friends and relatives) } \\
\text { expect me to collect selectively. (SN1) }\end{array}$ & $\square$ & $\square$ & 口 & 口 & $\square$ \\
\hline & & $\begin{array}{l}\text { Neighbors and other community members will criticize me if I } \\
\text { do not collect selectively. (SN2) }\end{array}$ & 口 & 口 & $\square$ & $\square$ & $\square$ \\
\hline & & $\begin{array}{l}\text { If all the members of the community I belong to collect } \\
\text { selectively, I will also start collecting selectively. (SN3) }\end{array}$ & $\square$ & $\square$ & $\square$ & $\square$ & $\square$ \\
\hline \multirow{2}{*}{ Responsibility } & \multirow{2}{*}{ RSP } & $\begin{array}{l}\text { I feel responsible to collect selectively to increase the amount of } \\
\text { waste recovered. (RSP1) }\end{array}$ & $\square$ & $\square$ & $\square$ & $\square$ & $\square$ \\
\hline & & $\begin{array}{l}\text { I feel responsible for the amount of waste that I generate and } \\
\text { that instead of being recycled, ends up in the landfill. (RSP2) }\end{array}$ & $\square$ & $\square$ & $\square$ & $\square$ & $\square$ \\
\hline \multirow[b]{2}{*}{ Reward } & \multirow[b]{2}{*}{ RW } & $\begin{array}{l}\text { I would be more likely to collect selectively if selective } \\
\text { collection programs involved a financial reward. (RW1) }\end{array}$ & $\square$ & $\square$ & $\square$ & $\square$ & $\square$ \\
\hline & & $\begin{array}{c}\text { I would be more likely to collect selectively if I received a } \\
\text { discount on the supermarket tax receipt for the packaging I } \\
\text { return. (RW2) }\end{array}$ & $\square$ & $\square$ & $\square$ & $\square$ & $\square$ \\
\hline \multirow[b]{2}{*}{ Taxation } & \multirow[b]{2}{*}{ TAX } & $\begin{array}{l}\text { If I were charged double for the amount of waste I did not } \\
\text { collect selectively, I would sort all the waste I produce. (TAX1) }\end{array}$ & $\square$ & $\square$ & $\square$ & $\square$ & $\square$ \\
\hline & & $\begin{array}{l}\text { If I wouldn't be charged extra for the amount of waste I don't } \\
\text { selectively collect, I wouldn't sort all the waste I } \\
\text { produce. (TAX2) }\end{array}$ & $\square$ & $\square$ & $\square$ & 口 & $\square$ \\
\hline
\end{tabular}

Appendix B Answers Distribution for Perceived Behavioral Control (PBC), Convenience (CON), Selective Collection Behavior (SCB), Government Measures (GM), Intention (INT), Waste Collection Infrastructure (INFR), Responsibility (RSP), Reward (RW) and Taxation (TAX)

Table A2. The answers distribution.

\begin{tabular}{ccccccc}
\hline Acronym & Questions ID & $\begin{array}{c}\text { Strongly } \\
\text { Disagree }\end{array}$ & Disagree & Neutral & Agree & $\begin{array}{c}\text { Strongly } \\
\text { Agree }\end{array}$ \\
\hline \multirow{2}{*}{ PCB } & PCB1 & $\begin{array}{c}213 \\
(30.65 \%)\end{array}$ & $\begin{array}{c}208 \\
(29.92 \%)\end{array}$ & $\begin{array}{c}157 \\
(22.59 \%)\end{array}$ & $\begin{array}{c}79 \\
(22.59 \%)\end{array}$ & $\begin{array}{c}38 \\
(5.47 \%)\end{array}$ \\
\cline { 2 - 7 } & PCB2 & 67 & 100 & 119 & 196 & 213 \\
& \multirow{2}{*}{ PCB3 } & $(9.64 \%)$ & $(14.39 \%)$ & $(17.12 \%)$ & $(28.20 \%)$ & $(30.65 \%)$ \\
\hline \multirow{2}{*}{ CON } & CON1 & $(34.96 \%)$ & $(21.87 \%)$ & $(18.42 \%)$ & $(15.54 \%)$ & $(9.21 \%)$ \\
\cline { 2 - 7 } & \multirow{2}{*}{ CON2 } & 45 & 51 & 132 & 239 & 228 \\
& & $(6.47 \%)$ & $(7.34 \%)$ & $(18.99 \%)$ & $(34.39 \%)$ & $(32.81 \%)$ \\
\hline
\end{tabular}


Table A2. Cont.

\begin{tabular}{|c|c|c|c|c|c|c|}
\hline Acronym & Questions ID & $\begin{array}{l}\text { Strongly } \\
\text { Disagree }\end{array}$ & Disagree & Neutral & Agree & $\begin{array}{c}\text { Strongly } \\
\text { Agree }\end{array}$ \\
\hline \multirow{5}{*}{ SCB } & SCB1 & $\begin{array}{c}38 \\
(5.47 \%)\end{array}$ & $\begin{array}{c}124 \\
(17.84 \%)\end{array}$ & $\begin{array}{c}174 \\
(25.04 \%)\end{array}$ & $\begin{array}{c}205 \\
(29.50 \%)\end{array}$ & $\begin{array}{c}154 \\
(22.16 \%)\end{array}$ \\
\hline & SCB2 & $\begin{array}{c}290 \\
(41.73 \%)\end{array}$ & $\begin{array}{c}180 \\
(25.90 \%)\end{array}$ & $\begin{array}{c}93 \\
(13.38 \%)\end{array}$ & $\begin{array}{c}75 \\
(10.79 \%)\end{array}$ & $\begin{array}{c}57 \\
(8.20 \%)\end{array}$ \\
\hline & SCB3 & $\begin{array}{c}64 \\
(9.21 \%)\end{array}$ & $\begin{array}{c}77 \\
(11.08 \%)\end{array}$ & $\begin{array}{c}78 \\
(11.22 \%)\end{array}$ & $\begin{array}{c}183 \\
(26.33 \%)\end{array}$ & $\begin{array}{c}293 \\
(42.16 \%)\end{array}$ \\
\hline & SCB4 & $\begin{array}{c}42 \\
(6.04 \%)\end{array}$ & $\begin{array}{c}40 \\
(5.76 \%)\end{array}$ & $\begin{array}{c}76 \\
(10.94 \%)\end{array}$ & $\begin{array}{c}182 \\
(26.19 \%)\end{array}$ & $\begin{array}{c}355 \\
(51.08 \%)\end{array}$ \\
\hline & SCB5 & $\begin{array}{c}42 \\
(6.04 \%)\end{array}$ & $\begin{array}{c}66 \\
(9.5 \%)\end{array}$ & $\begin{array}{c}96 \\
(13.81 \%)\end{array}$ & $\begin{array}{c}185 \\
(26.62 \%)\end{array}$ & $\begin{array}{c}306 \\
(44.03 \%)\end{array}$ \\
\hline \multirow{4}{*}{ GM } & GM1 & $\begin{array}{c}60 \\
(8.63 \%)\end{array}$ & $\begin{array}{c}60 \\
(8.63 \%)\end{array}$ & $\begin{array}{c}145 \\
(20.86 \%)\end{array}$ & $\begin{array}{c}130 \\
(18.71 \%)\end{array}$ & $\begin{array}{c}300 \\
(43.17 \%)\end{array}$ \\
\hline & GM2 & $\begin{array}{c}71 \\
(10.22 \%) \\
\end{array}$ & $\begin{array}{c}69 \\
(9.93 \%) \\
\end{array}$ & $\begin{array}{c}183 \\
(26.33 \%) \\
\end{array}$ & $\begin{array}{c}131 \\
(18.85 \%)\end{array}$ & $\begin{array}{c}241 \\
(34.68 \%) \\
\end{array}$ \\
\hline & GM3 & $\begin{array}{c}14 \\
(2.01 \%)\end{array}$ & $\begin{array}{c}12 \\
(1.73 \%)\end{array}$ & $\begin{array}{c}56 \\
(8.06 \%)\end{array}$ & $\begin{array}{c}186 \\
(26.76 \%)\end{array}$ & $\begin{array}{c}427 \\
(61.44 \%)\end{array}$ \\
\hline & GM4 & $\begin{array}{c}54 \\
(7.77 \%)\end{array}$ & $\begin{array}{c}65 \\
(9.35 \%)\end{array}$ & $\begin{array}{c}187 \\
(26.91 \%)\end{array}$ & $\begin{array}{c}155 \\
(22.30 \%)\end{array}$ & $\begin{array}{c}234 \\
(33.67 \%)\end{array}$ \\
\hline \multirow{3}{*}{ INT } & INT1 & $\begin{array}{c}13 \\
(1.87 \%)\end{array}$ & $\begin{array}{c}26 \\
(3.74 \%)\end{array}$ & $\begin{array}{c}136 \\
(19.57 \%)\end{array}$ & $\begin{array}{c}252 \\
(36.26 \%)\end{array}$ & $\begin{array}{c}268 \\
(38.56 \%)\end{array}$ \\
\hline & INT2 & $\begin{array}{c}47 \\
(6.76 \%)\end{array}$ & $\begin{array}{c}102 \\
(14.68 \%)\end{array}$ & $\begin{array}{c}245 \\
(35.25 \%)\end{array}$ & $\begin{array}{c}197 \\
(28.35 \%)\end{array}$ & $\begin{array}{c}104 \\
(14.96 \%)\end{array}$ \\
\hline & INT3 & $\begin{array}{c}16 \\
(2.30 \%)\end{array}$ & $\begin{array}{c}35 \\
(5.04 \%)\end{array}$ & $\begin{array}{c}139 \\
(20.00 \%)\end{array}$ & $\begin{array}{c}255 \\
(36.69 \%)\end{array}$ & $\begin{array}{c}250 \\
(35.97 \%)\end{array}$ \\
\hline \multirow{4}{*}{ INFR } & INFR1 & $\begin{array}{c}7 \\
(1.01 \%) \\
\end{array}$ & $\begin{array}{c}4 \\
(0.58 \%) \\
\end{array}$ & $\begin{array}{c}35 \\
(5.04 \%) \\
\end{array}$ & $\begin{array}{c}183 \\
(26.33 \%) \\
\end{array}$ & $\begin{array}{c}466 \\
(67.05 \%) \\
\end{array}$ \\
\hline & INFR2 & $\begin{array}{c}20 \\
(2.88 \%) \\
\end{array}$ & $\begin{array}{c}30 \\
(4.32 \%) \\
\end{array}$ & $\begin{array}{c}87 \\
(12.52 \%) \\
\end{array}$ & $\begin{array}{c}183 \\
(26.33 \%)\end{array}$ & $\begin{array}{c}389 \\
(55.97 \%) \\
\end{array}$ \\
\hline & INFR3 & $\begin{array}{c}15 \\
(2.16 \%)\end{array}$ & $\begin{array}{c}21 \\
(3.02 \%)\end{array}$ & $\begin{array}{c}118 \\
(16.98 \%)\end{array}$ & $\begin{array}{c}208 \\
(29.93 \%)\end{array}$ & $\begin{array}{c}333 \\
(47.91 \%)\end{array}$ \\
\hline & INFR4 & $\begin{array}{c}11 \\
(1.58 \%)\end{array}$ & $\begin{array}{c}6 \\
(0.86 \%)\end{array}$ & $\begin{array}{c}26 \\
(3.74 \%)\end{array}$ & $\begin{array}{c}158 \\
(22.73 \%)\end{array}$ & $\begin{array}{c}494 \\
(71.08 \%)\end{array}$ \\
\hline \multirow{2}{*}{ RSP } & RSP1 & $\begin{array}{c}10 \\
(1.44 \%)\end{array}$ & $\begin{array}{c}16 \\
(2.30 \%)\end{array}$ & $\begin{array}{c}70 \\
(10.07 \%)\end{array}$ & $\begin{array}{c}194 \\
(27.91 \%)\end{array}$ & $\begin{array}{c}405 \\
(58.27 \%)\end{array}$ \\
\hline & RSP2 & $\begin{array}{c}13 \\
(1.87 \%)\end{array}$ & $\begin{array}{c}17 \\
(2.45 \%)\end{array}$ & $\begin{array}{c}73 \\
(10.50 \%)\end{array}$ & $\begin{array}{c}207 \\
(29.78 \%)\end{array}$ & $\begin{array}{c}385 \\
(55.40 \%) \\
\end{array}$ \\
\hline \multirow{2}{*}{ RW } & RW1 & $\begin{array}{c}105 \\
(15.11 \%)\end{array}$ & $\begin{array}{c}171 \\
(24.60 \%)\end{array}$ & $\begin{array}{c}204 \\
(29.35 \%)\end{array}$ & $\begin{array}{c}118 \\
(16.98 \%)\end{array}$ & $\begin{array}{c}97 \\
(13.96 \%)\end{array}$ \\
\hline & RW2 & $\begin{array}{c}73 \\
(10.50 \%)\end{array}$ & $\begin{array}{c}96 \\
(13.81 \%)\end{array}$ & $\begin{array}{c}149 \\
(21.44 \%)\end{array}$ & $\begin{array}{c}207 \\
(29.78 \%)\end{array}$ & $\begin{array}{c}170 \\
(24.46 \%)\end{array}$ \\
\hline \multirow{2}{*}{ TAX } & TAX1 & $\begin{array}{c}66 \\
(9.50 \%) \\
\end{array}$ & $\begin{array}{c}72 \\
(10.36 \%)\end{array}$ & $\begin{array}{c}161 \\
(23.17 \%)\end{array}$ & $\begin{array}{c}141 \\
(20.29 \%)\end{array}$ & $\begin{array}{c}255 \\
(36.69 \%) \\
\end{array}$ \\
\hline & TAX2 & $\begin{array}{c}194 \\
(27.91 \%)\end{array}$ & $\begin{array}{c}149 \\
(21.44 \%)\end{array}$ & $\begin{array}{c}217 \\
(31.22 \%)\end{array}$ & $\begin{array}{c}77 \\
(11.08 \%)\end{array}$ & $\begin{array}{c}58 \\
(8.35 \%)\end{array}$ \\
\hline
\end{tabular}




\section{References}

1. Rai, R.K.; Nepal, M.; Khadayat, M.S.; Bhardwaj, B. Improving Municipal Solid Waste Collection Services in Developing Countries: A Case of Bharatpur Metropolitan City, Nepal. Sustainability 2019, 11, 3010. [CrossRef]

2. Rai, R.K.; Bhattarai, D.; Neupane, S. Designing solid waste collection strategy in small municipalities of developing countries using choice experiment. J. Urban Manag. 2019, 8, 386-395. [CrossRef]

3. Eurostat Statistics Eurostat-Recycling Rate of Municipal Waste. Available online: https://ec.europa.eu/ eurostat/databrowser/view/sdg_11_60/default/table?lang=en (accessed on 4 March 2019).

4. Hansmann, R.; Bernasconi, P.; Smieszek, T.; Loukopoulos, P.; Scholz, R.W. Justifications and self-organization as determinants of recycling behavior: The case of used batteries. Resour. Conserv. Recycl. 2006, 47, 133-159. [CrossRef]

5. World Bank Trends in Solid Waste Management. Available online: https://datatopics.worldbank.org/what-awaste/trends_in_solid_waste_management.html (accessed on 11 July 2020).

6. Lebreton, L.; Andrady, A. Future scenarios of global plastic waste generation and disposal. Palgrave Commun. 2019, 5, 1-11. [CrossRef]

7. Neagu, L. Minister of Environment Warns: Romania will Miss the 50\% Target for Waste Recycling at the End of the Year and We Will Pay Penalties. Available online: https:/www.green-report.ro/ministrul-mediului-avertizeazaromania-va-rata-tinta-de-50-pentru-reciclarea-deseurilor-la-finele-anului-si-vom-plati-penalizari/ (accessed on 16 July 2020).

8. Eurostat Municipal Waste by Waste Management Operations. Available online: https://appsso.eurostat.ec. europa.eu/nui/submitViewTableAction.do (accessed on 16 July 2020).

9. Romanian Government OUG 68 12/10/2016. Available online: http://legislatie.just.ro/Public/DetaliiDocument/ 182700 (accessed on 16 July 2020).

10. Li, W.; Achal, V. Environmental and health impacts due to e-waste disposal in China-A review. Sci. Total Environ. 2020, 737, 139745. [CrossRef]

11. ZWN the Zero Waste Network. Available online: http://www.zerowastenetwork.org/ (accessed on 16 July 2020).

12. ZWE European Zero Waste Municipalities-Compare European Cities' Performance with Resource Recovery. Available online: http://zerowasteeurope.eu/zerowastecities.eu/city/107 (accessed on 16 July 2020).

13. Boldero, J. The Prediction of Household Recycling of Newspapers: The Role of Attitudes, Intentions, and Situational Factors1. J. Appl. Soc. Psychol. 1995, 25, 440-462. [CrossRef]

14. Garcés, C.; Lafuente, A.; Pedraja, M.; Rivera, P. Urban waste recycling behavior: Antecedents of participation in a selective collection program. Environ. Manag. 2002, 30, 378-390. [CrossRef]

15. Tonglet, M.; Phillips, P.S.; Read, A.D. Using the Theory of Planned Behaviour to investigate the determinants of recycling behaviour: A case study from Brixworth, UK. Resour. Conserv. Recycl. 2004, 41, 191-214. [CrossRef]

16. Valle, P.O.D.; Rebelo, E.; Reis, E.; Menezes, J. Combining Behavioral Theories to Predict Recycling Involvement. Environ. Behav. 2005, 37, 364-396. [CrossRef]

17. Mahmud, S.N.D.; Osman, K. The determinants of recycling intention behavior among the Malaysian school students: An application of theory of planned behaviour. Procedia Soc. Behav. Sci. 2010, 9, 119-124. [CrossRef]

18. Lee, S.; Paik, H.S. Korean household waste management and recycling behavior. Build. Environ. 2011, 46, 1159-1166. [CrossRef]

19. Klöckner, C.A.; Oppedal, I.O. General vs. domain specific recycling behaviour-Applying a multilevel comprehensive action determination model to recycling in Norwegian student homes. Resour. Conserv. Recycl. 2011, 55, 463-471. [CrossRef]

20. Latif, S.A.; Omar, M.S.; Bidin, Y.H.; Awang, Z. Environmental Problems and Quality of Life: Situational Factor as a Predictor of Recycling Behaviour. Procedia Soc. Behav. Sci. 2012, 35, 682-688. [CrossRef]

21. Bezzina, F.H.; Dimech, S. Investigating the determinants of recycling behaviour in Malta. Manag. Environ. Qual. Int. J. 2011, 22, 463-485. [CrossRef]

22. Wan, C.; Shen, G.Q.; Yu, A. The role of perceived effectiveness of policy measures in predicting recycling behaviour in Hong Kong. Resour. Conserv. Recycl. 2014, 83, 141-151. [CrossRef] 
23. Amini, F.; Ahmad, J.; Ambali, A.R. The Influence of Reward and Penalty on Households' Recycling Intention. APCBEE Procedia 2014, 10, 187-192. [CrossRef]

24. Byrne, S.; O'Regan, B. Attitudes and actions towards recycling behaviours in the Limerick, Ireland region. Resour. Conserv. Recycl. 2014, 87, 89-96. [CrossRef]

25. Nguyen, T.T.P.; Zhu, D.; Le, N.P. Factors influencing waste separation intention of residential households in a developing country: Evidence from Hanoi, Vietnam. Habitat Int. 2015, 48, 169-176. [CrossRef]

26. Yahya, W.K.; Musa, N.D.; Hashim, N.H. Understanding Environmentally Friendly Consumer Behavior. In Regional Conference on Science, Technology and Social Sciences (RCSTSS 2014); Abdullah, M.A., Yahya, W.K., Ramli, N., Mohamed, S.R., Ahmad, B.E., Eds.; Springer: Singapore, 2016; pp. 909-921, ISBN 978-981-10-1456-7.

27. Hynes, N.; Wilson, J. I do it, but don't tell anyone! Personal values, personal and social norms: Can social media play a role in changing pro-environmental behaviours? Technol. Forecast. Soc. Chang. 2016, 111, 349-359. [CrossRef]

28. Miliute-Plepiene, J.; Hage, O.; Plepys, A.; Reipas, A. What motivates households recycling behaviour in recycling schemes of different maturity? Lessons from Lithuania and Sweden. Resour. Conserv. Recycl. 2016, 113, 40-52. [CrossRef]

29. Yuan, Y.; Nomura, H.; Takahashi, Y.; Yabe, M. Model of Chinese Household Kitchen Waste Separation Behavior: A Case Study in Beijing City. Sustainability 2016, 8, 1083. [CrossRef]

30. Zhang, S.; Zhang, M.; Yu, X.; Ren, H. What keeps Chinese from recycling: Accessibility of recycling facilities and the behavior. Resour. Conserv. Recycl. 2016, 109, 176-186. [CrossRef]

31. Nduneseokwu, C.; Qu, Y.; Appolloni, A. Factors Influencing Consumers' Intentions to Participate in a Formal E-Waste Collection System: A Case Study of Onitsha, Nigeria. Sustainability 2017, 9, 881. [CrossRef]

32. Nguyen, T.; Nguyen, H.; Lobo, A.; Dao, T. Encouraging Vietnamese Household Recycling Behavior: Insights and Implications. Sustainability 2017, 9, 179. [CrossRef]

33. Pop, I.N.; de Ramírez, G.M.S.; Baciu, C.; Bican-Brișan, N.; Muntean, O.L.; Costin, D. Life cycle analysis in evaluation of household waste collection and transport in Cluj-Napoca, Romania. AES Bioflux 2017, 9, 17-29.

34. Meng, X.; Tan, X.; Wang, Y.; Wen, Z.; Tao, Y.; Qian, Y. Investigation on decision-making mechanism of residents' household solid waste classification and recycling behaviors. Resour. Conserv. Recycl. 2019, 140, 224-234. [CrossRef]

35. Rosenthal, S. Procedural Information and Behavioral Control: Longitudinal Analysis of the Intention-Behavior Gap in the Context of Recycling. Recycling 2018, 3, 5. [CrossRef]

36. Strydom, W. Applying the Theory of Planned Behavior to Recycling Behavior in South Africa. Recycling 2018, 3, 43. [CrossRef]

37. Sujata, M.; Khor, K.-S.; Ramayah, T.; Teoh, A.P. The role of social media on recycling behaviour. Sustain. Prod. Consum. 2019, 20,365-374. [CrossRef]

38. Ng, S.-L. Predicting multi-family dwelling recycling behaviors using structural equation modelling: A case study of Hong Kong. Resour. Conserv. Recycl. 2019, 149, 468-478. [CrossRef]

39. Thi Thu Nguyen, H.; Hung, R.-J.; Lee, C.-H.; Thi Thu Nguyen, H. Determinants of Residents' E-Waste Recycling Behavioral Intention: A Case Study from Vietnam. Sustainability 2019, 11, 164. [CrossRef]

40. Wang, B.; Ren, C.; Dong, X.; Zhang, B.; Wang, Z. Determinants shaping willingness towards on-line recycling behaviour: An empirical study of household e-waste recycling in China. Resour. Conserv. Recycl. 2019, 143, 218-225. [CrossRef]

41. Pamuk, S.; Kahriman-Pamuk, D. Preservice Teachers' Intention to Recycle and Recycling Behavior: The Role of Recycling Opportunities. Int. Electron. J. Environ. Educ. 2018, 9, 33-45.

42. Delcea, C.; Crăciun, L.; Ioanăs, C.; Ferruzzi, G.; Cotfas, L.-A. Determinants of Individuals' E-Waste Recycling Decision: A Case Study from Romania. Sustainability 2020, 12, 2753. [CrossRef]

43. Halder, P.; Singh, H. Predictors of Recycling Intentions among the Youth: A Developing Country Perspective. Recycling 2018, 3, 38. [CrossRef]

44. Delcea, C.; Popa, C.D.S.; Boloş, M. Consumers' Decisions in Grey Online Social Networks. J. Grey Syst. $2015,27$.

45. Delcea, C.; Cotfas, L.-A.; Trică, C.; Crăciun, L.; Molanescu, A. Modeling the Consumers Opinion Influence in Online Social Media in the Case of Eco-friendly Products. Sustainability 2019, 11, 1796. [CrossRef]

46. Chen, C.-C.; Chen, C.-W.; Tung, Y.-C. Exploring the Consumer Behavior of Intention to Purchase Green Products in Belt and Road Countries: An Empirical Analysis. Sustainability 2018, 10, 854. [CrossRef] 
47. Ajzen, I. From Intentions to Actions: A Theory of Planned Behavior. In Action Control: From Cognition to Behavior; Kuhl, J., Beckmann, J., Eds.; SSSP Springer Series in Social Psychology; Springer: Berlin/Heidelberg, Germany, 1985; pp. 11-39, ISBN 978-3-642-69746-3.

48. Ajzen, I. The theory of planned behavior. Organ. Behav. Hum. Decis. Process. 1991, 50, 179-211. [CrossRef]

49. Chu, P.-Y.; Chiu, J.-F. Factors Influencing Household Waste Recycling Behavior: Test of an integrated Model1. J. Appl. Soc. Psychol. 2003, 33, 604-626. [CrossRef]

50. Davies, J.; Foxall, G.R.; Pallister, J. Beyond the Intention-Behaviour Mythology: An Integrated Model of Recycling. Mark. Theory 2002, 2, 29-113. [CrossRef]

51. Miafodzyeva, S.; Brandt, N. Recycling Behaviour Among Householders: Synthesizing Determinants Via a Meta-analysis. Waste Biomass Valorization 2013, 4, 221-235. [CrossRef]

52. Davis, G.; Morgan, A. Using the Theory of Planned Behaviour to determine recycling and waste minimisation behaviours: A case study of Bristol City, UK. Spec. Ed. Pap. 2008, 20, 105-117.

53. Kite, J.; Gale, J.; Grunseit, A.; Li, V.; Bellew, W.; Bauman, A. From awareness to behaviour: Testing a hierarchy of effects model on the Australian Make Healthy Normal campaign using mediation analysis. Prev. Med. Rep. 2018, 12, 140-147. [CrossRef] [PubMed]

54. Schwartz, S.H. Normative Influences on Altruism. In Advances in Experimental Social Psychology; Berkowitz, L., Ed.; Academic Press: New York, NY, USA, 1977; Volume 10, pp. 221-279.

55. Grob, A. A structural model of environmental attitudes and behaviour. J. Environ. Psychol. 1995, 15, $209-220$. [CrossRef]

56. IBM. IBM SPSS Amos. Available online: https://www.ibm.com/ro-en/marketplace/structural-equationmodeling-sem (accessed on 6 March 2020).

57. Byrne, B.M. Structural Equation Modeling with AMOS: Basic Concepts, Applications, and Programming, 3rd ed.; Routledge: New York, NY, USA, 2016; ISBN 978-1-317-63312-9.

58. Spanos, Y.E.; Lioukas, S. An examination into the causal logic of rent generation: Contrasting Porter's competitive strategy framework and the resource-based perspective. Strateg. Manag. J. 2001, 22, 907-934. [CrossRef]

59. Delcea, C.; Bradea, I.-A. Patients' perceived risks in hospitals: A grey qualitative analysis. Kybernetes 2017, 46, 1408-1424. [CrossRef]

60. Hu, L.; Bentler, P.M. Cutoff criteria for fit indexes in covariance structure analysis: Conventional criteria versus new alternatives. Struct. Equ. Model. A Multidiscip. J. 1999, 6, 1-55. [CrossRef]

61. Brown, T.A. Confirmatory Factor Analysis for Applied Research, 2nd ed.; Methodology in the social sciences; The Guilford Press: New York, NY, USA; London, UK, 2015; ISBN 978-1-4625-1779-4.

62. Harrington, D. Confirmatory Factor Analysis; Pocket guides to social work research methods; Oxford University Press: Oxford, UK; New York, NY, USA, 2009; ISBN 978-0-19-533988-8.

63. Paswan, A.; D'Souza, D.; Zolfagharian, M.A. Toward a Contextually Anchored Service Innovation Typology. Decis. Sci. 2009, 40, 513-540. [CrossRef]

64. Hair, J.F.; Black, W.C.; Babin, B.J.; Anderson, R.E. Multivariate Data Analysis, 7th ed.; Pearson: Upper Saddle River, NJ, USA, 2009; ISBN 978-0-13-813263-7.

65. Sarstedt, M.; Ringle, C.M.; Hair, J.F. Partial Least Squares Structural Equation Modeling. In Handbook of Market Research; Homburg, C., Klarmann, M., Vomberg, A., Eds.; Springer International Publishing: Cham, Switzerland, 2017; pp. 1-40, ISBN 978-3-319-05542-8.

66. Arcury, T.A.; Scollay, S.J.; Johnson, T.P. Sex differences in environmental concern and knowledge: The case of acid rain. Sex Roles 1987, 16, 463-472. [CrossRef]

67. Saladié, Ò.; Santos-Lacueva, R. The role of awareness campaigns in the improvement of separate collection rates of municipal waste among university students: A Causal Chain Approach. Waste Manag. 2016, 48, 48-55. [CrossRef] [PubMed]

68. Duffett, R.; Edu, T.; Haydam, N.; Negricea, I.-C.; Zaharia, R. A Multi-Dimensional Approach of Green Marketing Competitive Advantage: A Perspective of Small Medium and Micro Enterprises from Western Cape, South Africa. Sustainability 2018, 10, 3764. [CrossRef]

(C) 2020 by the authors. Licensee MDPI, Basel, Switzerland. This article is an open access article distributed under the terms and conditions of the Creative Commons Attribution (CC BY) license (http://creativecommons.org/licenses/by/4.0/). 